\title{
A STUDY OF THE MECHANISMS OF EDEMA FORMATION IN PATIENTS WITH THE NEPHROTIC SYNDROME ${ }^{1}$
}

\author{
BY H. A. EDER, ${ }^{2}$ H. D. LAUSON,2 F. P. CHINARD, 3 R. L. GREIF, 2 G. C. COTZIAS, \\ AND D. D. VAN SLYKE 4 \\ (From the Hospital of the Rockefeller Institute for Medical Research, New York, N. Y.)
}

(Submitted for publication May 12, 1953; accepted December 31, 1953)

Accumulation of edema in the nephrotic syndrome is the result of renal tubular reabsorption of filtered sodium, chloride, and water in excess of that required for maintenance of a normal extracellular fluid volume. This increase in tubular reabsorption ("glomerulo-tubular imbalance" (3, 4)) could be the consequence of a decrease in the rate of glomerular filtration ("primary glomerular insufficiency") or of stimuli acting directly on the tubules ("primary tubular preponderance").

Decreased glomerular filtration rate (GFR) could be due directly to glomerular lesions (2) or might be related to a decrease in renal blood flow secondary to decreased plasma volume with "inadequacy" of the general circulation-a milder form of the insufficiency present in shock $(5,6)$. Changes in GFR due to lesions are the result of changes in the area and/or characteristics of the filtering surface. Adjustment to circulatory "inadequacy" which results in decreased renal blood flow would presumably be accomplished mainly by constriction of the afferent arterioles with reduction of pressure in the glomerular capillaries. GFR would diminish if this decrease in net transcapillary hydrostatic pressure were greater than the decrease in so-called colloid osmotic pressure due to hypoalbuminemia. Circulatory factors would be expected to reduce GFR by roughly the same proportion in most glomeruli ( 7 ); however, morphologic alterations may vary greatly from one glomerulus to another. The degree of glomerular insufficiency resulting from the combined effects of

\footnotetext{
1 Presented in part at the Forty-First Annual Meeting of the American Society for Clinical Investigation at Atlantic City, N. J., May 2, 1949. Summaries of some of the data have been published elsewhere $(1,2)$.

2 Present Address: Cornell University Medical College, New York, N. Y.

- Present Address : Johns Hopkins School of Medicine, Baltimore, Md.

\& Present Address: Brookhaven National Laboratory, Upton, N. Y.
}

these extra- and intra-renal factors might, therefore, vary considerably from nephron to nephron.

The present studies were carried out in an attempt to assess the importance of glomerular insufficiency in the pathogenesis of edema in the nephrotic syndrome. Most measurements were made before, during, and after periods of diuresis which were either spontaneous or induced by administration of concentrated human plasma albumin. ${ }^{5}$ Because small changes in the glomerular filtration rate can result in disproportionately large changes in salt and water excretion (8-11), the technic of around-the-clock clearances, in which measurements are made in successive clearance periods continuing over one or more days, was frequently used.

\section{METHODS}

Chloride concentration was determined by the silver iodate method $(12,13)$. In analyzing urines with very high concentrations of albumin, the proteins were precipitated with a solution containing $10 \mathrm{Gm}$. of hydrated picric acid per liter of $0.15 \mathrm{M}$ phosphoric acid. Sodium was determined in a Model 52A Perkin-Elmer flame photometer with lithium as internal standard. Urea nitrogen in protein-free filtrates of blood or plasma and of urine was measured by the gasometric hypobromite method (14). $P$-aminohippurate (PAH) was measured by the method described by Goldring and Chasis (15). Other methods have been previously described $(16,17)$.

Excretion of chloride or sodium was measured concurrently with the endogenous "creatinine" clearance $\left(C_{c r}\right)$ (16) in around-the-clock studies in four patients (A. McE., C. M., L. B., and S. G.). In two children in whom spontaneous diuresis occurred, 24-hour chloride excretion and routine morning urea clearances were measured at irregular intervals before, during, and after the diuresis (B. M. and S. M.). In one child, excretion of chloride and $C_{e r}$ were measured on 24-hour urine specimens (K. S.).

- Supplied by the National Blood Program of the American Red Cross. The opinions are those of the authors and do not necessarily represent those of the American Red Cross. 


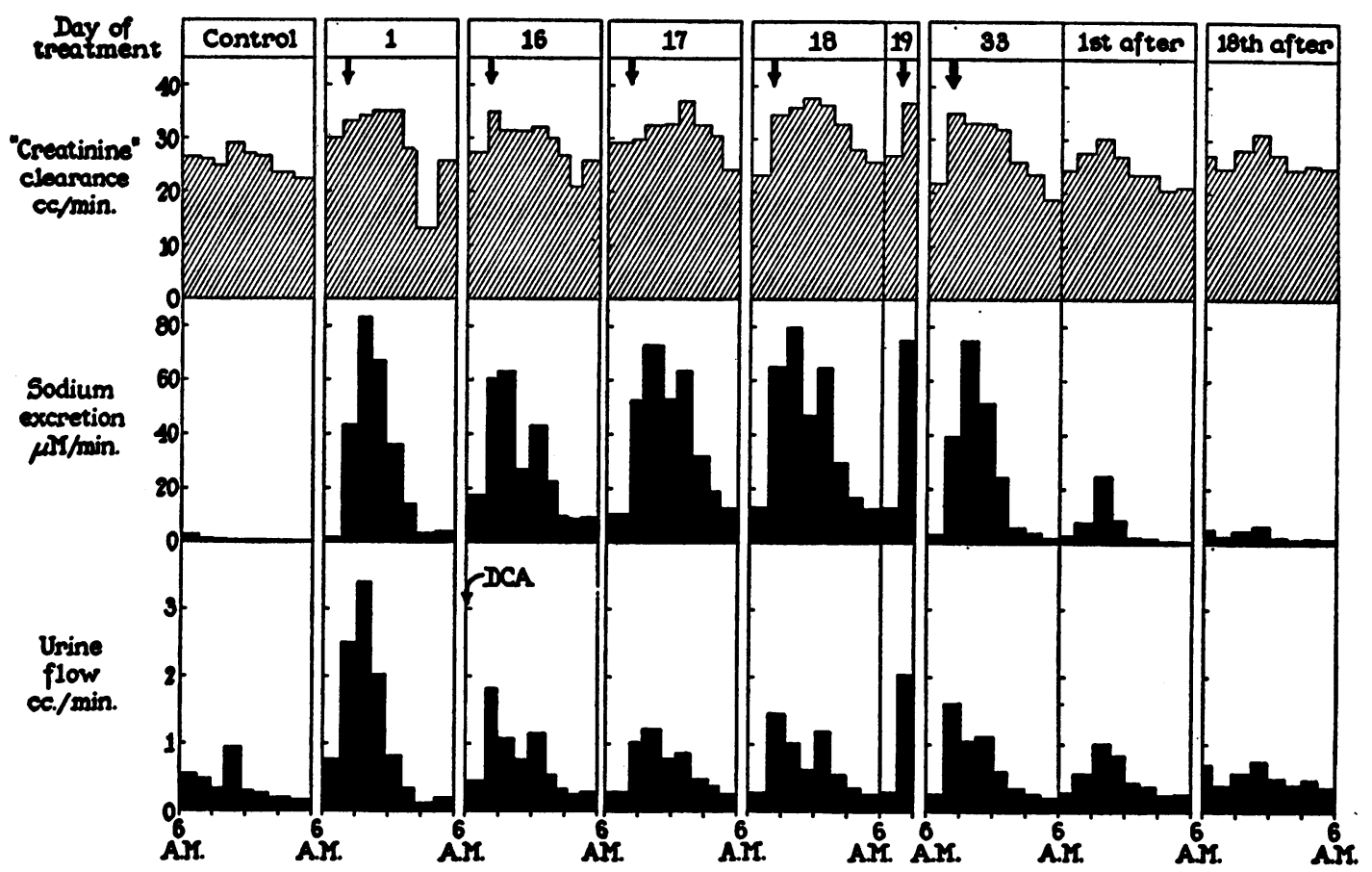

Fig. 1. Summary of Around-the-Clock Data on A. McE. (Female, Age 51/2 Years; Onset of Illness, 28 Months Previously) Before, During and After a 33-Day Course of Albumin Therapy

The essential data have been simplified by combining measurements from contiguous periods into approximately three-hour intervals. This gives all periods equal weight and minimizes bladder emptying errors (all urines were voided). The data as actually observed and including other measurements are shown in Figure 15 in the Appendix.

The arrows at the top indicate administration of $25 \mathrm{Gm}$. of albumin as 25 per cent solution, except on day 33 when $37.5 \mathrm{Gm}$. were given. On the 16th day (Nov. 16-17, 1948) $5 \mathrm{mg}$. of desoxycorticosterone acetate were injected intramuscularly (see Figures 14 and 15 in the Appendix for other effects of the hormone). On the 18th day after the last albumin infusion (Dec. 21-22) excretion of chloride was measured instead of sodium. By this time considerable edema had reaccumulated and the measurements were again similar to those of the control day (Oct. 27-28, 1948). During each of these days fluids as such were ingested approximately as follows: 6 a.m., $200 \mathrm{ml}$.; $8: 30$ a.m., $200 \mathrm{ml}$.; $10: 30$ a.m., $200 \mathrm{ml}$.; $12: 45$ p.m., 150 ml.; 2 p.m., 200 ml.; $3: 15$ p.m., 100 ml.; 5 :30 p.m., 150 ml.; total, 1200 ml.

\section{RESULTS}

\section{Albumin-induced diuresis}

Taken as a whole, the data show a good correlation in a large number of the clearance periods between change in $\mathrm{C}_{\mathrm{cr}}$ and change in salt excretion. This is most clearly seen in the data on A. McE. (Figures 1 and 2 ) whose $C_{c r}$ after a course of albumin therapy returned to the pre-treatment level, thus providing satisfactory after-control as well as fore-control data.

In acute experiments on C. M., the renal clearances of PAH $\left(\mathrm{C}_{\mathrm{PAB}}\right)$ and "creatinine" increased after albumin administration (Figure 3). During the several months of observation, $\mathrm{C}_{\mathrm{cr}}$ rose steadily. Nevertheless, as shown in Figure 4, there was a fairly good correlation between acute increases in $\mathrm{C}_{\mathrm{cr}}$ and increases in salt and water excretion on many of the days in which albumin was administered; this was especially the case during the first two weeks of December, 1947 when diuresis was most profuse. In Figure 5, the chloride excretions of Figure 4 are related to concurrent $C_{c r}$. Because of the steady increase in $\mathrm{C}_{\mathrm{cr}}$ during the period of study, it was thought appropriate to divide the data into successive groups in which the initial $\mathrm{C}_{\mathrm{er}}$ 's were similar. From the data of Figure 5 , it is probable that factors other than change in 
$\mathrm{C}_{\mathrm{cr}}$ also influenced chloride excretion in this patient.

In patient L. B. (Figure 6) albumin therapy failed on most days to induce diuresis. Correlated with this is the fact that $\mathrm{C}_{\mathrm{cr}}$ showed little tendency to increase, even though plasma volume was expanded considerably. On those days in which salt and water excretion did increase moderately, $\mathrm{C}_{c r}$ also increased in most of the periods concerned.

\section{Spontaneous diuresis}

In patient K. S. (Figure 7) albumin therapy induced only slight diuresis; during the month of treatment, 24-hour $\mathrm{C}_{\mathrm{cr}}$ and routine urea clearances increased gradually. Some weeks later, spontaneous diuresis (perhaps related in part to the paracentesis) occurred after $\mathrm{C}_{\mathrm{cr}}$ had increased further. In B. M. (Figure 8) and S. M., (Figure 9) pro- fuse diuresis and complete loss of edema occurred spontaneously in association with a return to normal of the previously depressed urea clearance.

Diuresis associated with supernormal renal clearances

The above data indicate that an increased excretion of sodium, chloride, and water in edematous patients is often associated with an increase in GFR (as estimated by increase in $\mathrm{C}_{\mathrm{cr}}$ ) following albumin administration or occurring spontaneously. Conversely, it is possible that edema accumulation in these patients was associated with a decrease in GFR. However, edema occurs also in some patients in whom GFR and other discrete renal functions are normal or even supernormal (19-22). It is evident, therefore, that even though GFR is within or above the statistical range of normal it

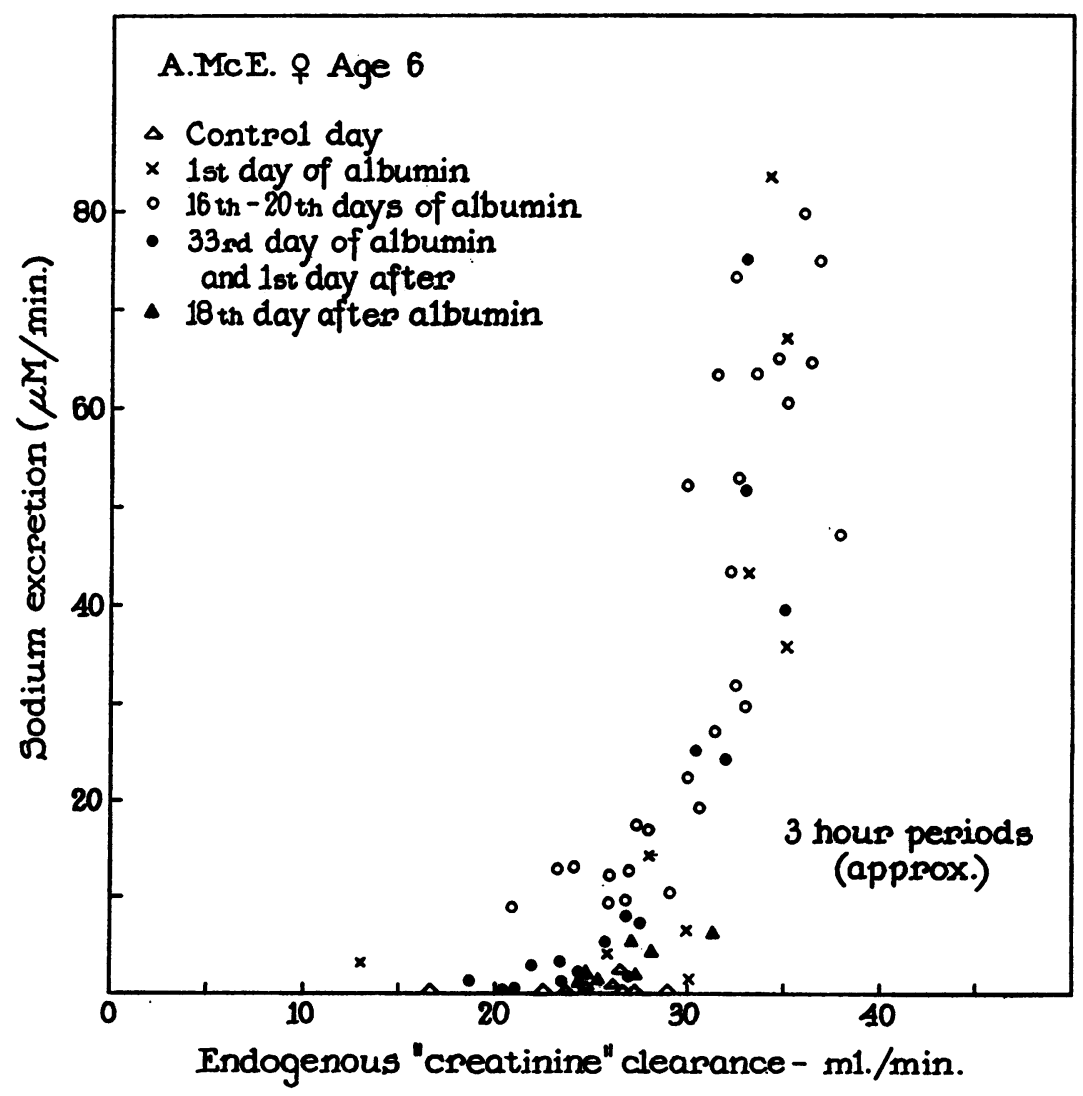

Frg. 2. Data of Figure 1 Plotted to Show Sodium Excretion as a Function of $\mathrm{C}_{\text {er }}$ 


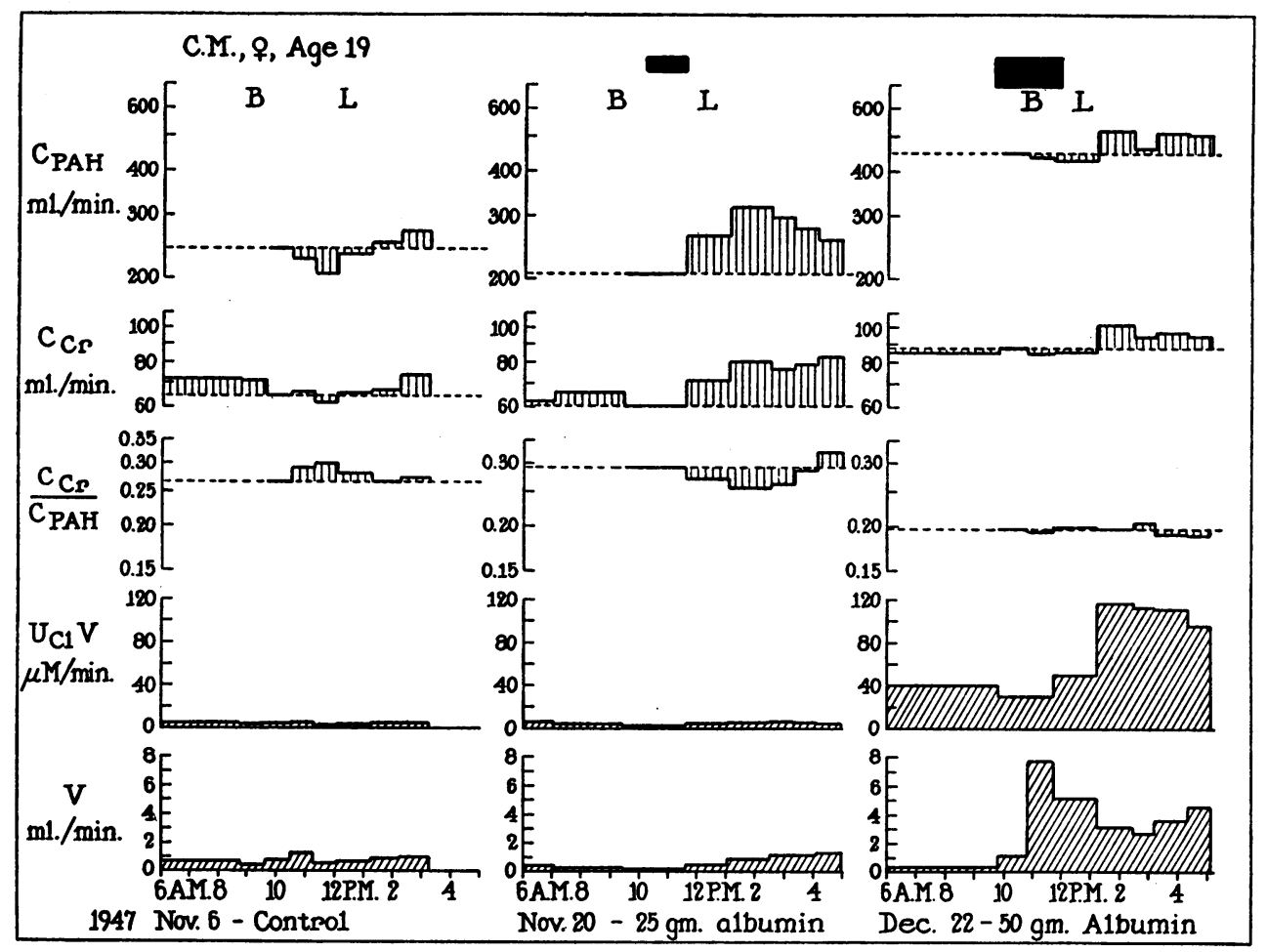

Fig. 3. Data on C. M. (Female, Age 19 Years ; Onset of Illness, Six Months Previously) before and during a Course of Albumin Therapy

Renal clearances of PAH ( $\left.\mathrm{C}_{P A B}\right)$ and "creatinine" $\left(\mathrm{C}_{\mathrm{er}}\right)$, excretion of chloride $\left(\mathrm{U}_{\mathrm{Cl}_{1} \mathrm{~V}}\right)$ and urine flow (V) were measured on a control day and on two days in which 25 and $50 \mathrm{Gm}$. of albumin, respectively, were administered as 10 per cent solution. The horizontal dash lines indicate the clearance values during the initial PAH period on each day; changes are indicated by the hatched lines. $B$ and $L$ indicate the time of breakfast and lunch. The solid blocks represent the time of the albumin infusion. Urines were collected by catheterization. See Figure 16 in the Appendix for additional data on this patient.

may nevertheless be low relative to the tubular activities concerned with reabsorption of sodium, chloride, and water.

In S. G., a patient with supernormal renal functions (Table I), the around-the-clock data shown in Figure 10 were obtained. On the day shown on the left, albumin was administered. The control observations in the middle section were made after albumin therapy had been withheld for two days. Edema reaccumulated until, after an interval of decreasing proteinuria and rising plasma albumin concentration, a spontaneous diuresis began five weeks later. On the fifth day of this diuresis, the study shown on the right was carried out. The data suggest some relationship between diu- resis and chloruresis and increase in $\mathrm{C}_{\mathrm{cr}}$, even though $\mathrm{C}_{\mathrm{er}}$ was in the range of normal to supernormal and even though the 24-hour mean $\mathrm{C}_{\text {cr }}$ was about the same on these three days $(126,122$, and $129 \mathrm{ml}$. per min.). The lack of an exact correspondence in certain periods between increases in $\mathrm{C}_{\mathrm{er}}$ and in chloride and water excretion indicates the operation of additional factors.

Perhaps related to the problem of fluid retention in patients with supernormal GFR are the data of Table I. From these data and those of others (1922), it is evident that in this type of patient the maximum tubular excretory capacity $\left(\mathrm{Tm}_{\mathrm{PAB}}\right)$ and reabsorptive capacity $\left(\mathrm{Tm}_{\mathrm{glucose}}\right)$ usually are increased more than are GFR or $\mathrm{C}_{\mathbf{P A H}}$. It is obvious 
that renal reabsorption of sodium and water does not necessarily parallel the tubular activity in regard to $\mathrm{PAH}$ and glucose transport. Nevertheless, these data are at least compatible with the concept that even in patients with supernormal kidney functions, GFR is insufficient relative to tubular activity.

\section{DISCUSSION}

The concept that primary glomerular insufficiency results in excessive reabsorption of sodium, chloride, and water rests firmly on results of animal experiments by Marshall and Kolls (27), Shannon (28), Selkurt, Hall, and Spencer (8, 29, 30), Pitts and Duggan (9), Mueller, Surtshin, Carlin, and White (10), Post (31), Thompson and Pitts (11) and others. These experiments show that as GFR is reduced, either acutely or chronically, there is a disproportionately large reduction in the excretion of sodium and water. This reduction is largely independent of the antidiuretic and adrenocortical hormones and of the renal nerve supply (11). In most of these animal studies the reduction of GFR probably reflected a fairly uniform decrease in the filtration rate of all nephrons. This statement is based on the fact that $\mathrm{Tm}_{\mathrm{glucose}}$ and $\mathrm{Tm}_{\mathrm{PAB}}$ remain relatively normal until GFR is reduced to less than half of the control value $(7,32)$.

Severe circulatory insufficiency due to trauma or hemorrhage results in marked reduction of GFR $(5,6)$. A lesser reduction in GFR can be induced in man by passive tilting $(33,34)$; this induces the same disproportionately large decrease in water and salt excretion in man as is found in dogs after GFR is decreased by reduction in renal arterial pressure (8-11). A similar relationship of sodium excretion to $\mathrm{C}_{\mathrm{cr}}$ was illustrated in Figure 2.

The hypothesis that primary glomerular insufficiency is an important factor in the fluid retention of the nephrotic syndrome finds more direct support in the data of other investigators $(35-38)$ : diuresis following treatment with corticotropin

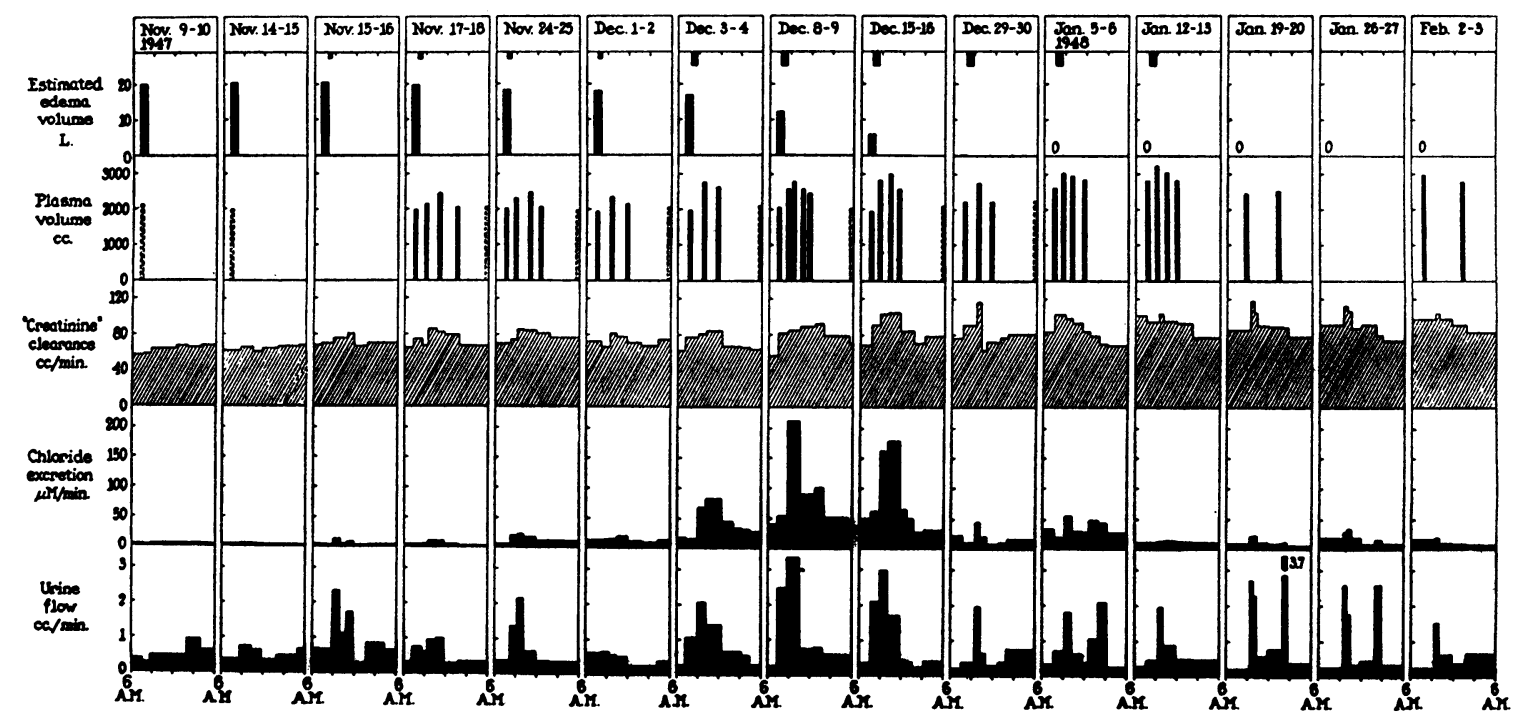

Fig. 4. Summary of Around-the-Clock Data on C. M.

The solid blocks under the dates indicate the time and and quantity (25 or $50 \mathrm{Gm}$.) of the albumin infusion. Edema volume was estimated by subtracting the body weight on Dec. 31,1947 (43.7 $\mathrm{Kg}$.), at which time all edema had disappeared, from the body weight of each previous day shown. Plasma volumes indicated by stippled columns were estimated from values found at a corresponding time of the day on a preceding or following day. The patient fully recovered during these observations; proteinuria disappeared by Jan. 19, 1948. Fluids as such were not given according to a rigid schedule, but the total daily intake was kept constant at $1500 \mathrm{ml}$. See Figure 16 in the Appendix for additional data. 


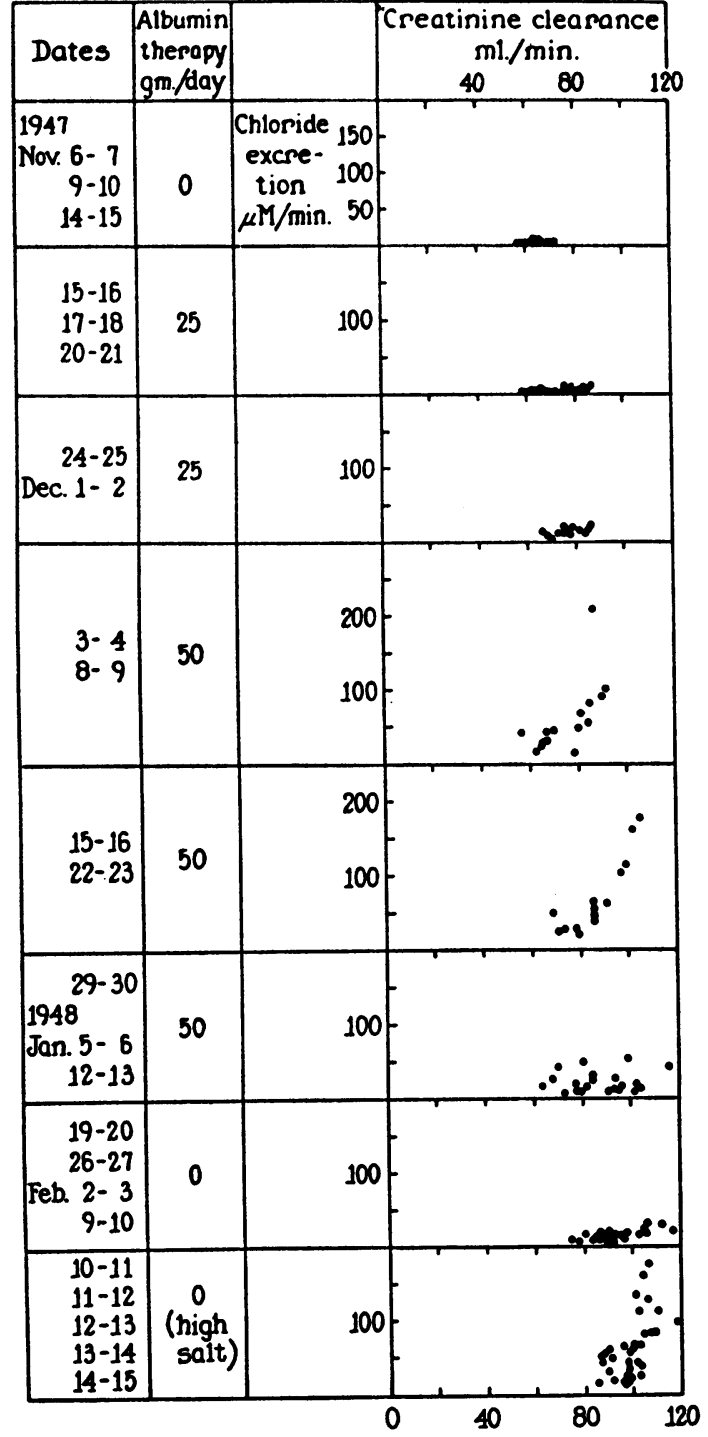

Fig. 5. Chloride Excretion as a Function of Cer IN C. $M$.

Most of the data are the same as shown in Figure 4. The bottom row shows results obtained continuously during five days following abrupt increase of sodium chloride intake from 21 to $123 \mathrm{mM}$ per day. The patient had fully recovered by this time. Body weight increased $2.3 \mathrm{Kg}$. during this five-day interval. The 24-hour chloride excretion was $25.5 \mathrm{mM}$ on Feb. 9-10 and increased to 57, 77, 89,118 , and $131 \mathrm{mM}$ on the succeeding days. The data suggest that some of the increase in chloride excretion was related to increase in $C_{\text {er. }}$. However, comparison of these data with those of the row next to the bottom strongly suggests that in addition the tubules decreased their reabsorption of chloride as an adaptation to the increased salt intake. See also Figure 16 in the Appendix.
(ACTH) or Cortisone has, almost without exception, been associated with an increase in GFR. Our data on spontaneous diuresis (Figures 8 and 9) show a similar association of diuresis with increased GFR (as indicated by the urea clearance).

In patients with this disease, the excessive sodium reabsorbing activity of the tubules is strikingly revealed when sodium salts of unreabsorbable anions such as thiosulfate or PAH are administered in large amounts. In normal subjects during such administration, the anion excretion is matched by an equivalent excretion of sodium. However, when these substances are given to edematous patients with the nephrotic syndrome, the urinary anions are "covered" to a large extent by potassium (39-41). During remission following $\mathrm{ACTH}$ therapy, the pattern reverts toward normal in association with an increase in GFR (41). This excessive reabsorption of sodium could, of course, be due to primary tubule changes. In fact, other investigators (42) showed that a similar though limited tendency existed during sodium PAH loading in normal subjects receiving ACTH or Cortisone. However, Lauson and Thompson (43) have observed that the same phenomenon occurs in anesthetized normal dogs when GFR is reduced by inflation of a balloon located in the aorta above the renal arteries. There is no reason to believe that tubule function was primarily altered by any known mechanism; Thompson and Pitts (11) found that reduction in sodium excretion induced by this technic was apparently related only to decreased GFR and was independent of endocrine or neural influences.

The various possible mechanisms involved in edema formation are summarized schematically in Figure 11. We believe that the initial pathologic changes in the glomeruli may have two functional effects : 1) Reduction in the effective filtering surface, which directly decreases GFR; and 2) increase in the glomerular permeability to albumin and other plasma proteins (16). The resulting albuminuria lowers the plasma albumin concentration. This would be expected to result in a continuing shift of fluid from plasma to interstitial spaces which would be limited by secondary changes in mean capillary and tissue hydrostatic pressures (17). Diminution in plasma volume 

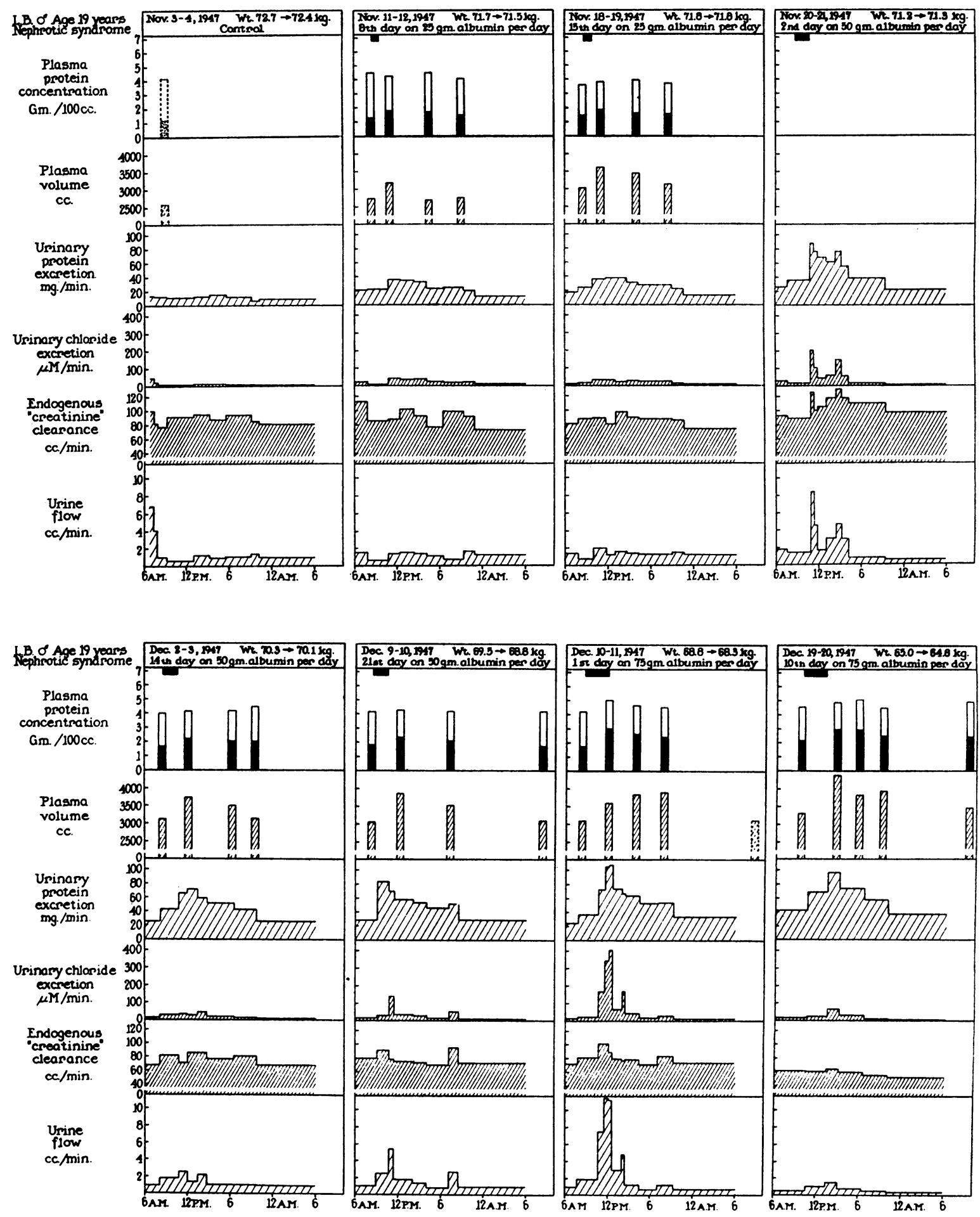

(Fig. 6 continued on opposite page) 
would be likely, and in this circumstance circulatory "inadequacy" could develop.

It has been difficult to determine whether the plasma volume is actually reduced. In the past, errors in the measurement of plasma volume by dye dilution methods have been large because of the hyperlipemia occurring in these patients (44). Moreover, the reductions are likely to be only small or moderate (as compared to those in severe hemorrhage or burns). Thus, the only really adequate control values would be those in the patient himself before the onset of the illness or after complete recovery. We have data on only one patient in whom this rigorous criterion was satisfied : in C. M., the plasma volume which repeatedly measured about $2100 \mathrm{ml}$. during the phase of severe edema increased to and stabilized at values around $2800 \mathrm{ml}$. after recovery (see Figure 16 in the Appendix). The corresponding whole blood volumes were about $3200 \mathrm{ml}$. and $4200 \mathrm{ml}$., respectively. Another patient, A. McE., was studied during two phases of severe edema (Oct. 6, 1948 and Feb. 6, 1949) and again in Nov.,
1949 when she was practically free of edema as the result of a spontaneous partial remission (see Figure 14 in the Appendix). The first plasma and blood volumes were about $1000 \mathrm{ml}$. and $1450 \mathrm{ml}$., respectively; during the remission they were $1150 \mathrm{ml}$. and $1750 \mathrm{ml}$. , respectively. During the interval her height increased from $106.0 \mathrm{~cm}$. to 111.5 cm.; it would be expected that as a result of this growth her blood volume would have increased by about $100 \mathrm{ml}$. $(45,46)$.

In most patients the development of circulatory "inadequacy" is probably sufficiently gradual so that frank symptoms occur uncommonly. In some, however, severe proteinuria may appear quite suddenly and symptoms suggestive of circulatory insufficiency arise. Such a sequence was observed in S. G. and is summarized in Figure 12. Protein excretion increased suddenly from about $5 \mathrm{Gm}$. per $24 \mathrm{hr}$. to $16 \mathrm{Gm}$. per $24 \mathrm{hr}$., plasma albumin con-

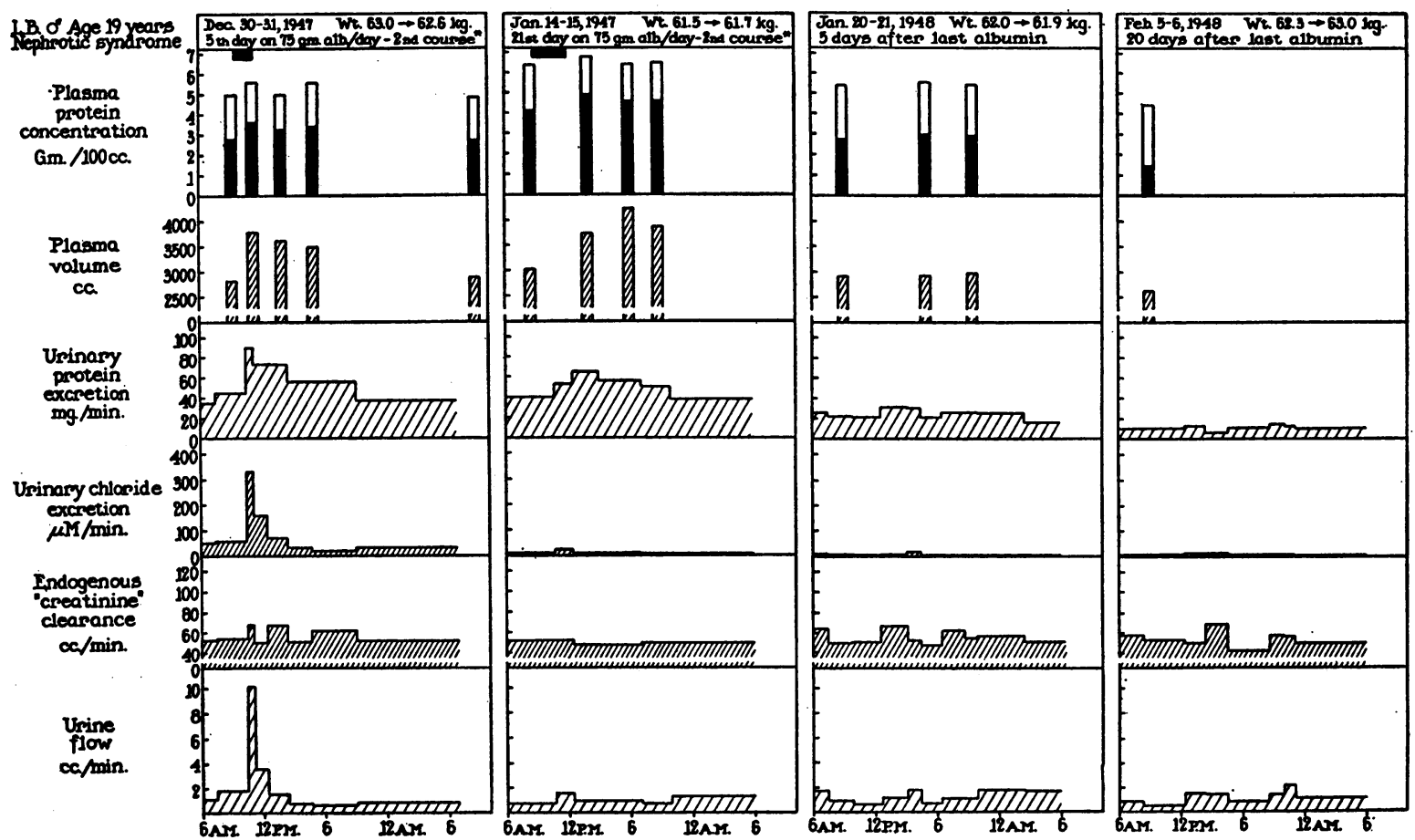

Fig. 6 A, B, C. Summary of Around-the-Clock Data on L. B. (Male, Age 19 Years; Onset of Illness, 40 Months Previously) before, during, and after a Course of Albumin Therapy

The solid block at top of upper row represents the time during which albumin was administered as 10 per cent solution. The solid columns in upper row indicate plasma albumin concentration (Howe's method). Plasma protein concentrations and plasma volumes represented by dotted lines were estimated from values at corresponding times on preceding or succeeding days. Note the gradual decline in $\mathrm{C}_{\mathrm{cr}}$ as renal function slowly deteriorated. During the period of these observations 24-hour fluid intake was $2400 \mathrm{ml}$. On Dec. 20, albumin therapy was stopped because of a severe upper respiratory illness with asthma. On Dec. 26 , it was resumed as a second course $\left(^{*}\right)$. 


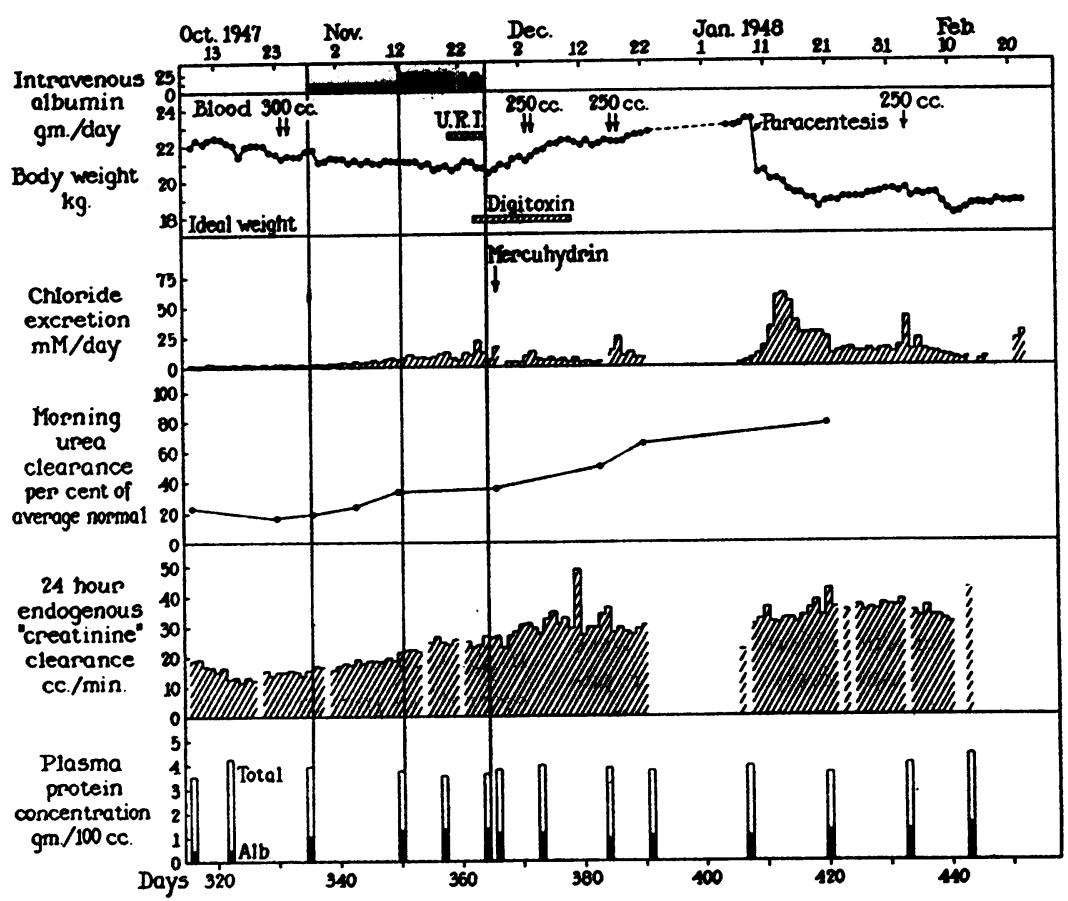

Fig. 7. Summary of Data on K. S. (Male, Age Four and One-Half Years; ONset of Illness, Three Years Previously) before, during, and after a Course of Albumin Therapy

$U . R . I$. indicates severe upper respiratory infection which was accompanied by dyspnea, weakness and gallop rhythm; these symptoms disappeared after albumin therapy was stopped and as the infection subsided. $C_{e r}$ was calculated as the 24-hour excretion (in mg. per min.) divided by the plasma concentration (in mg. per ml.) of creatinine-like chromogen measured each morning. During the period of albumin therapy, the urea clearance and plasma protein concentrations were measured in the morning prior to the albumin infusion; albumin was estimated by Howe's method.

centration fell from 1.7 to $1.2 \mathrm{Gm}$. per $100 \mathrm{ml}$., and the plasma volume decreased from about $2700 \mathrm{ml}$. to $2100 \mathrm{ml}$. As these changes were occurring, the patient experienced mild vertigo, feelings of faintness, palpitation, and thirst. After administration of albumin the plasma volume increased and the symptoms disappeared.

The primary glomerular insufficiency consequent to circulatory "inadequacy" and/or decrease in area and characteristics of the filtering surface has already been discussed. The observation that periods of increased salt and water excretion did not always correspond to periods of increased $\mathrm{C}_{\mathrm{er}}$ indicates that other (tubular) factors were operative. Evidence suggesting that primary tubular preponderance may play a part in the genesis of edema in the nephrotic syndrome has been reviewed recently (2). Possible factors are antidiuretic substances and adrenal cortical hormones $(36,37,47-$ 55 ), increased intrarenal pressure due to renal interstitial edema or to ascites $(29,56-58)$ and autonomic nerve influences (59-62). The view that tubular reabsorption of sodium is influenced by the renal nerves is opposed by Surtshin, Mueller, and White (63) and by Berne (64). Nothing is as yet known of the mechanisms whereby any of these factors are brought into operation.

The sequential relationship of some of the mechanisms shown in Figure 11 is well illustrated by the data on A. McE. presented in Figure 13. Daily administration of albumin had resulted in the loss of all edema in this five and one-half year old 


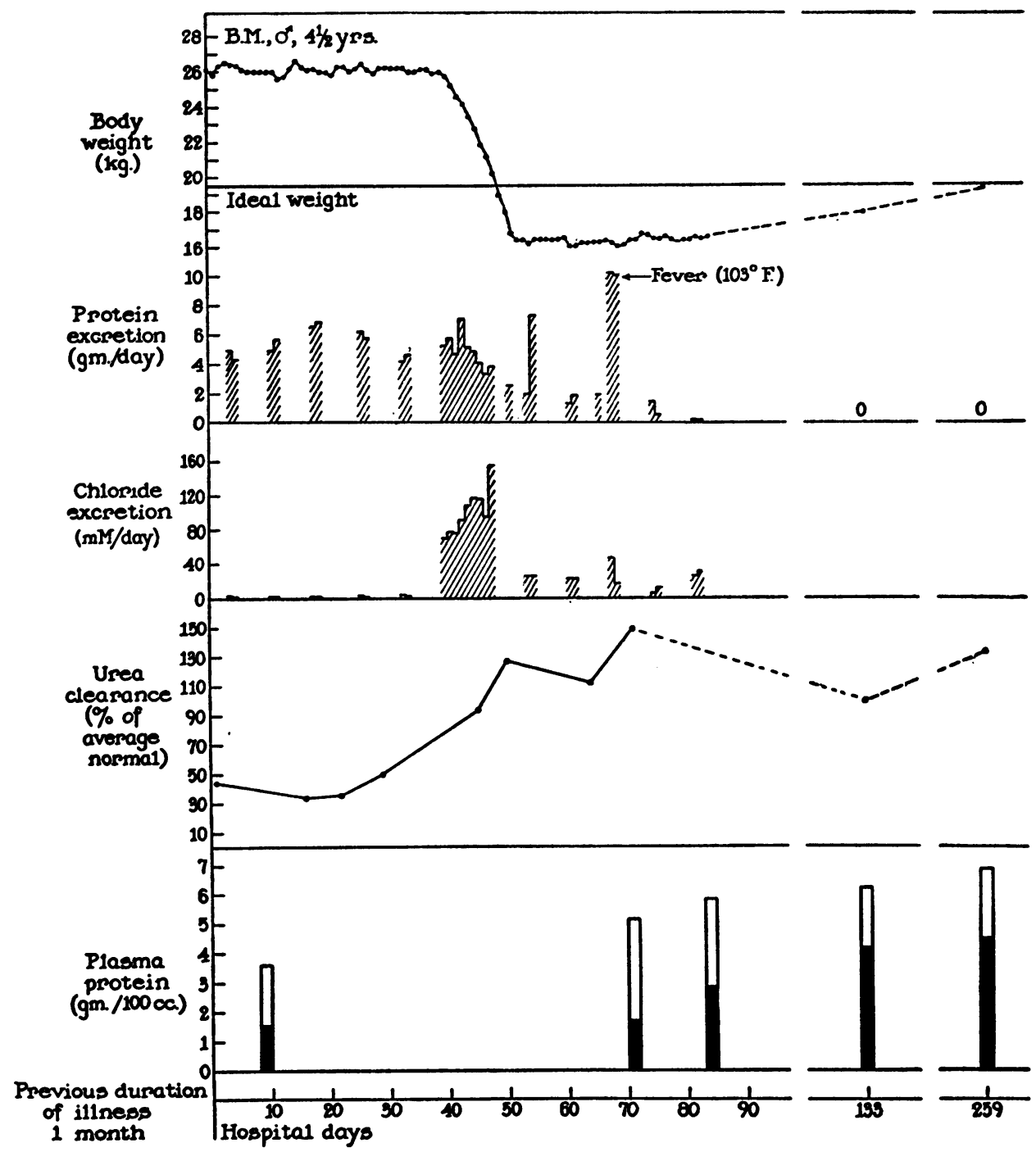

Fig. 8. Summary of Data on B. M. (Male, Age Four and One-Half Years; Onset of Illness, One Month Previously) Who Exhibited Spontaneous Diuresis with Complete Recoverry

Protein excretion was estimated by the Shevky-Stafford method (18). The solid columns in the lowest row indicate plasma albumin measured by Howe's method. 


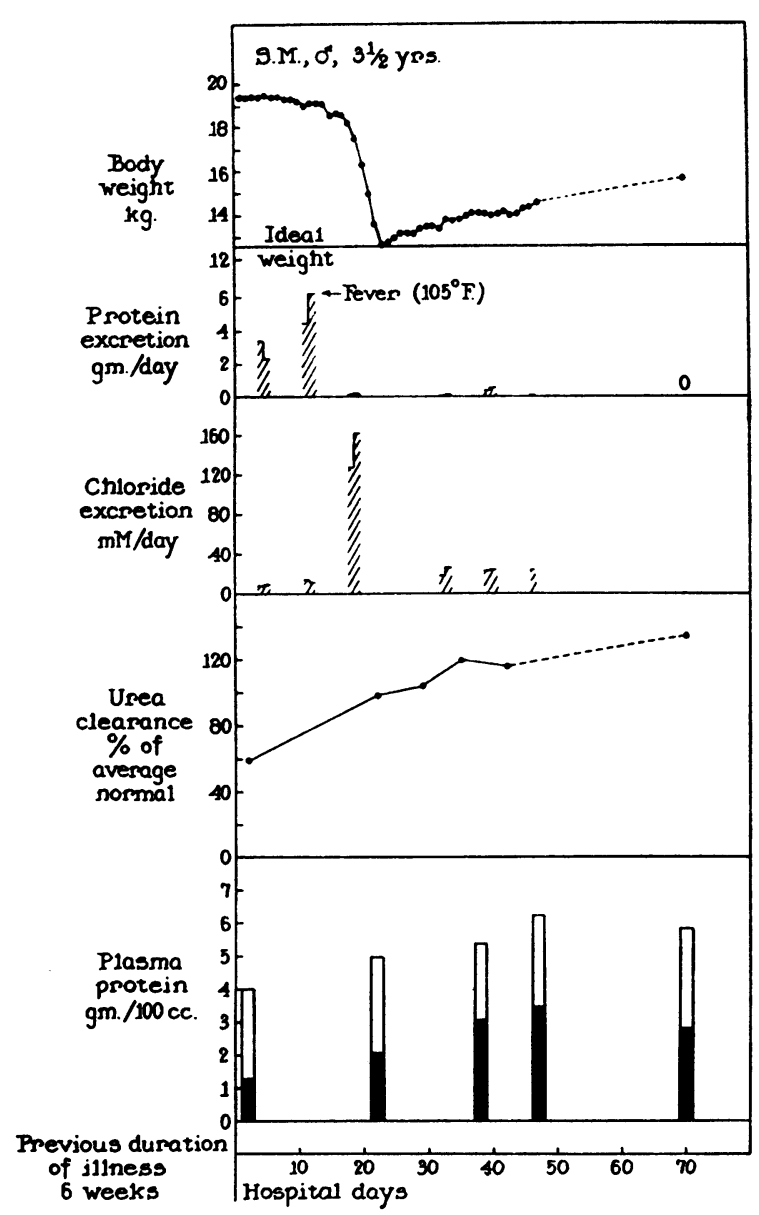

Fig. 9. Sumgary of Data on S. M. (Male, Age Three and One-Half Years; Onset of Disease, One and One-Half Months Previously) Who Exhibited Spontaneous Diuresis with Complete Recovery

See legend to Figure 8 for methods.

girl. Restoration toward normal of plasma albumin concentration, plasma volume, and $\mathrm{C}_{\mathrm{cr}}$ had followed each infusion. The changes which followed the final dose give some indication of how rapidly these measurements might decrease at the onset of the nephrotic syndrome as a result of sudden development of massive albuminuria.

\section{CONCLUSION}

Any current hypothesis of the mechanism of edema accumulation in the nephrotic syndrome is necessarily tentative. There is general agreement that the retention of water, sodium, and chloride is the result of glomerulo-tubular imbalance. Still undecided is the question as to which is the more important cause of the excessive tubular reabsorption: "primary glomerular insufficiency" or "primary tubular preponderance." It is our opinion that glomerular insufficiency is present in most patients with this syndrome. We regard this mechanism as the more fundamental: if GFR were sufficiently depressed, the salt and water retention would occur regardless of factors acting directly on the tubules. When GFR is only slightly depressed or is in the normal range, these tubular factors may be more significant.

\section{SUM MARY}

An attempt has been made to determine the importance of insufficiency of glomerular filtration as a cause of the excessive renal tubular reabsorption of salt and water in patients with the nephrotic syndrome.

Following the administration of concentrated human plasma albumin, the clearance of endogenous creatinine-like chromogen $\left(\mathrm{C}_{\mathrm{cr}}\right)$ increased in most patients; this increase correlated fairly well with increase in excretion of sodium, chloride, and water in a large number of clearance periods.

In three patients, spontaneous diuresis was associated with an increase in $\mathrm{C}_{\mathrm{cr}}$ or urea clearance.

Even in a patient with normal to supernormal $\mathrm{C}_{\mathrm{er}}$, there was some relationship between diuresis and chloruresis and further acute increase in $\mathrm{C}_{\mathrm{cr}}$. In this type of patient, other tubule functions ( $\mathrm{Tm}$ for glucose and $p$-aminohippurate) were elevated above normal to a greater extent than was glomerular filtration rate.

The fact that periods of change in salt and water excretion did not always correspond to periods of change in $\mathrm{C}_{\mathrm{cr}}$ suggests the operation of additional (tubular) factors. The relative importance of the two types of glomerulo-tubular imbalance ("primary glomerular insufficiency" and "primary tubular preponderance") in the causation of water and salt retention in the nephrotic syndrome cannot be assessed at present.

\section{APPENDIX}

Case summaries of A. McE. and C. M. are presented below to provide background information which will permit a more adequate evaluation of the data from the special 

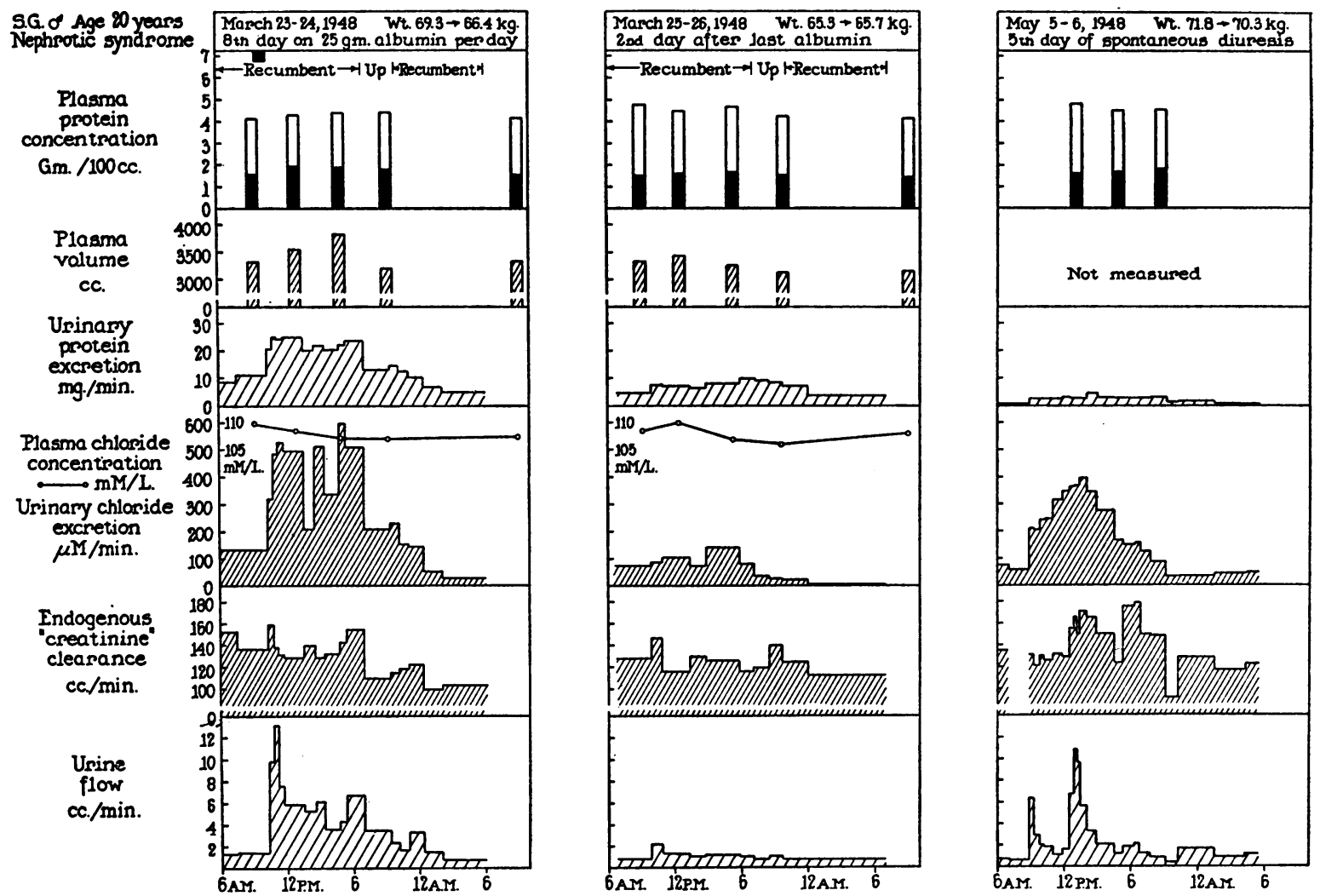

Fig. 10. Summary of Around-the-Clock Data on S. G. (Male, Age 20 Years; Onset of Illness, Five and One-Half Years Previously) from a Day in Which Diuresis Followed Albumin Infusion (at Time Indicated by Solid Block at Top of Upper Row on Left), a Day of Fluid Accumulation after Cessation of Albumin Treatment, and a Day of Spontaneous Diuresis

The solid columns in the upper row indicate albumin concentration measured by Howe's method. Total intake of fluids as such was 2100,2000 , and $1800 \mathrm{ml}$. on these days, respectively.

TABLE I

Supernormal tubular functions in patients with the nephrotic syndrome*

\begin{tabular}{|c|c|c|c|c|c|c|c|c|c|c|c|}
\hline $\begin{array}{l}\text { Patient } \\
\text { and } \\
\text { date }\end{array}$ & Sex & Age & $\begin{array}{c}\text { Ideal } \\
\text { surface } \\
\text { area }\end{array}$ & GFRt & $\mathrm{C}_{\mathrm{PAB}}$ & $\operatorname{Tm}_{\text {PAB }} \ddagger$ & $\mathrm{Tm}_{\mathrm{G}} \delta$ & $\frac{\text { GFR }}{C_{\text {PAH }}}$ & $\frac{\mathrm{C}_{\mathrm{PAH}}}{\mathrm{T}_{\mathrm{PAH}}}$ & $\frac{\text { GFR }}{\text { Tm }_{P A H}}$ & $\frac{\text { GFR }}{T m_{G}}$ \\
\hline \multirow{3}{*}{$\begin{array}{c}\text { Normal \|I } \\
\text { C. C. } \\
12-4-46 \\
3-4-47 \\
4-24-47 \\
5-13-47 \\
6-26-47\end{array}$} & \multirow{3}{*}{ F } & yrs. & $M^{2}$ & $\begin{array}{c}\text { ml. } / \text { min } \\
127\end{array}$ & $\begin{array}{c}\operatorname{ml.} / \min . \\
655\end{array}$ & $\begin{array}{c}\text { mg./min. } \\
77\end{array}$ & $\begin{array}{c}m g . / m i n . \\
375\end{array}$ & 0.19 & 8.4 & 1.6 & 0.34 \\
\hline & & \multirow[t]{2}{*}{5} & \multirow{2}{*}{$\begin{array}{l}0.794 \\
0.805 \\
0.805 \\
0.805 \\
0.816\end{array}$} & \multirow{2}{*}{$\begin{array}{l}160 \\
127 \\
148 \\
125 \\
139\end{array}$} & 1120 & 203 & \multirow{2}{*}{679} & 0.14 & 5.5 & 0.79 & \multirow{2}{*}{0.19} \\
\hline & & & & & $\begin{array}{l}840 \\
922 \\
887\end{array}$ & $\begin{array}{l}160 \\
138 \\
165\end{array}$ & & $\begin{array}{l}0.18 \\
0.14 \\
0.16\end{array}$ & $\begin{array}{l}5.2 \\
6.7 \\
5.4\end{array}$ & $\begin{array}{l}0.92 \\
0.91 \\
0.84\end{array}$ & \\
\hline $\begin{array}{l}\text { K.S. } \\
2-18-47\end{array}$ & $\mathbf{M}$ & 4 & 0.671 & 146 & 548 & 161 & & 0.27 & 3.4 & 0.91 & \\
\hline $\begin{array}{c}\text { J. B. } \\
\text { 4-47 }\end{array}$ & $\mathbf{M}$ & 4 & 0.752 & 147 & & 196 & & & & 0.75 & \\
\hline $\begin{array}{c}\text { S. G. } \\
12-14-48 \\
12-17-48\end{array}$ & $\mathbf{M}$ & 20 & $\begin{array}{l}1.66 \\
1.66\end{array}$ & $\begin{array}{l}138 \\
155\end{array}$ & 833 & 115 & 603 & 0.17 & 7.2 & 1.2 & 0.26 \\
\hline
\end{tabular}

* All values are corrected to a surface area of 1.73 square meters on the basis of height and ideal weight (23).

$\dagger$ Mannitol (24) clearance in C. C., K. S., and J. B.; inulin clearance in S. G.

The unbound fraction of plasma PAH was estimated from the nomogram of Taggart (25).

Glucose was determined by slight modification of the method of Miller and Van Slyke (26).

Mean values for adult males were taken from Smith (1), pages 91 and 544.

Renal functions had decreased considerably below these values by the time that the observations shown in Figure 7 were made. 


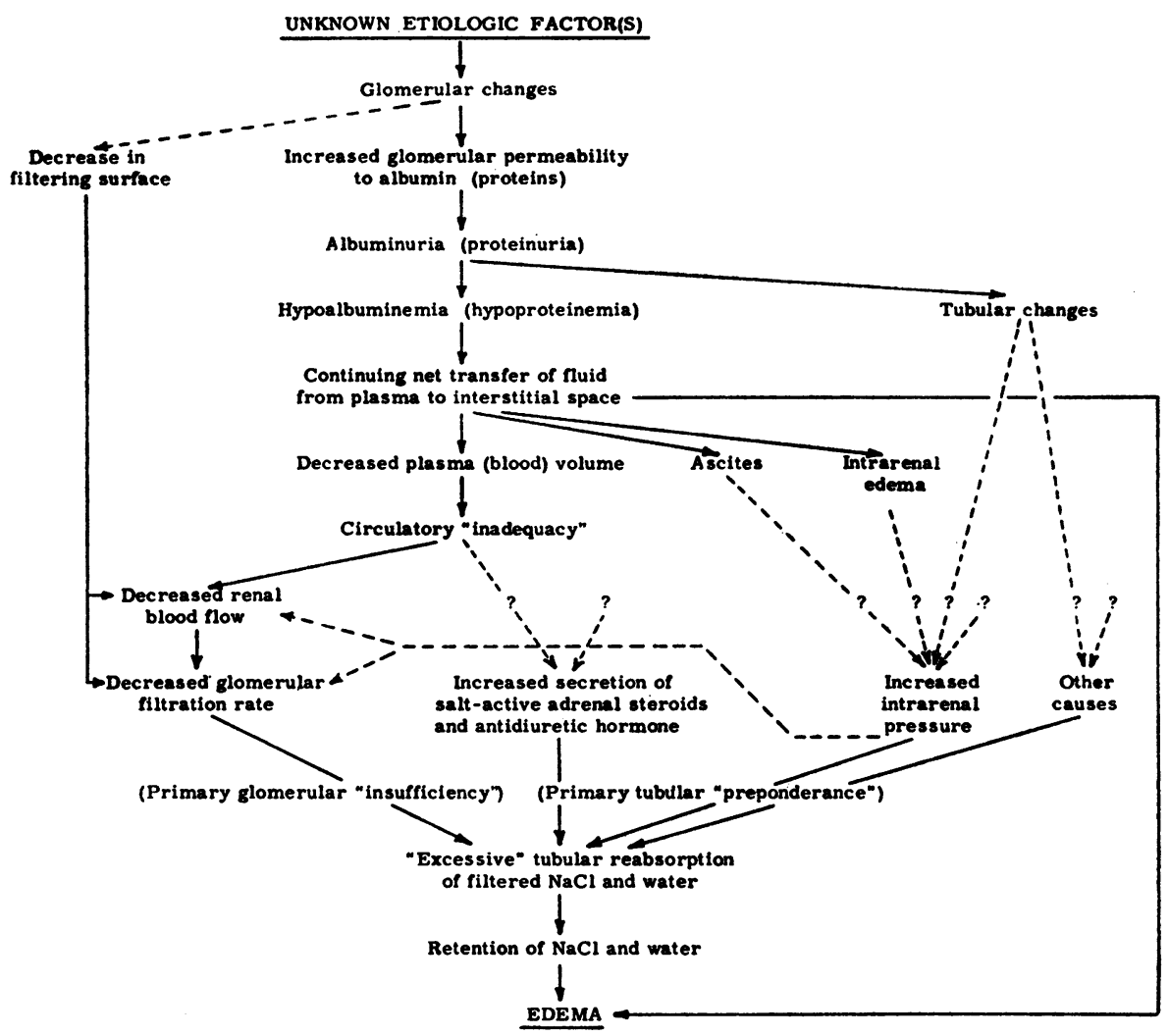

Fig. 11. Possible Mechanisms in the Pathogenesis of Edema in the Nephrotic SyNDROME

The line connecting "Glomerular changes" to "Decrease in filtering surface" is broken to indicate that such decrease does not always occur, as judged from the observation that in some patients GFR may be normal or supernormal and from the histologic evidence that glomerular lesions are minimal in some cases. Decrease of pressure in partially or completely obstructed glomerular capillaries would decrease GFR. It is also possible that the glomerular lesions may cause afferent arteriolar constriction locally. The term "Decrease in filtering surface" is intended to apply to both of these circumstances. 


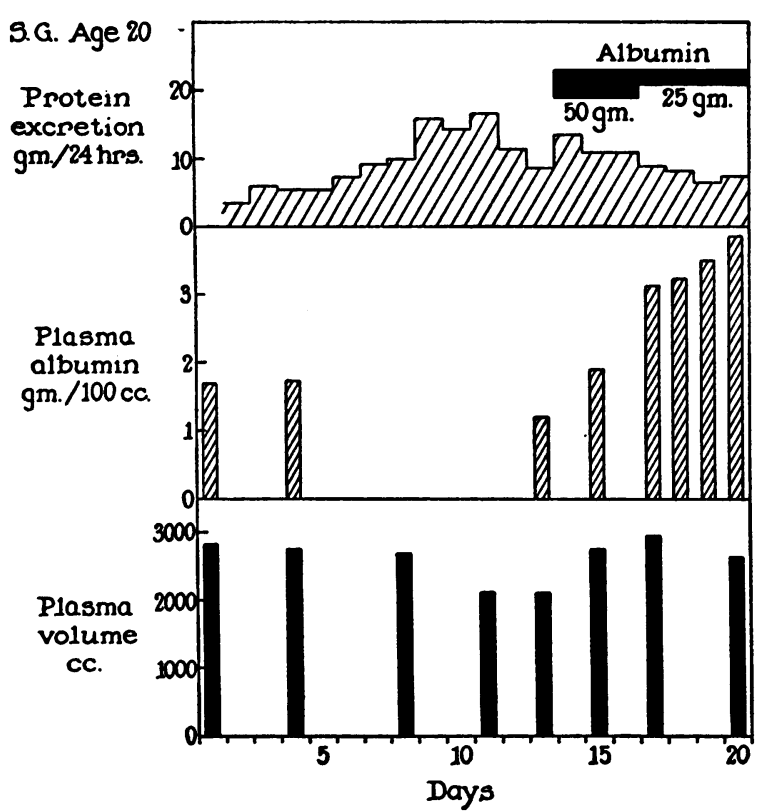

Fig. 12. Effect on Plasma Albumin Concentration (Howe's Method) and on Plasma Volume of Sudden Spontaneous Increase in Protein Excretion

The patient had only a moderate amount of edema and had been admitted for another purpose a few days earlier. Routine 24-hour urine collections and hemoglobin and plasma protein measurements were made. On about day 10 , the patient began to complain of the symptoms described in the Text. Plasma volume was measured by the T-1824 method the next morning and on the subsequent days shown. Plasma volumes on days 1,4 , and 8 were then estimated in retrospect as follows: From the hemoglobin values of days 1,4 , and 8 and from the average of the mean corpuscular hemoglobin determined on three later days, estimates of the hematocrits for days 1,4 , and 8 were made. These values (ht) were substituted in the equation, $V_{e}^{\prime \prime}=V_{\text {BBO }}(1.00-0.955 \mathrm{ht}) / 0.955 \mathrm{ht}$, where $\mathrm{V}_{e}$ " is the calculated plasma volume for day 1,4 , or 8 and $V_{\text {RBC }}$ is the volume of red cells (assumed constant) calculated from the T-1824 volume and hematocrit measured on day 11.

studies described in the present report and in the preceding papers of the series $(16,17,65)$.

A. MCE. (RIH 12,352). This 5-year old female was admitted to the Hospital of the Rockefeller Institute on Sept. 23, 1948 because of recurrent generalized edema during a two year period. Physical examination showed severe generalized edema and ascites; the blood pressure was $115 / 90$.

This patient's course during a period of one and onehalf years is summarized in Figure 14. During each hospital admission the diet was kept nearly constant with re- spect to protein (40 to $50 \mathrm{Gm}$. per day), total fluids and chloride (15 to $20 \mathrm{mM}$ per day). During each of the four courses of intravenous albumin the patient lost all of her edema; since Nov. 1949, edema has not been demonstrable. During the first course the decrease in thiocyanate (SCN) space (66) and the increase in chloride excretion suggest that the weight loss was almost all due to loss of extracellular fluid. Moreover, during the period of diuresis, the molar concentration ratio of $\mathrm{Na} / \mathrm{Cl}$ in urine approached that found in the extracellular fluid (plasma). In the sixth row of the figure, the scale from 0 to 50 indicates $\mathrm{ml}$. per $\mathrm{min}$. and refers to "creatinine" and inulin clearances; the scale from 0 to 100 per cent of normal applies to urea clearances which were corrected for surface area on the basis of height and ideal weight (23). During the periods of albumin therapy, the data of the bottom two rows were obtained in the morning prior to the day's infusion of albumin. Blood volume had increased moderately by the time of the partial remission in Nov., 1949. In the bottom row, the hatched column indicates albumin concentration as estimated by the Howe method; the solid column represents albumin measured immunochemically (16). Details of around-the-clock experiments carried out during the first admission are shown in Figure 15.

C. $M$. (RIH 12,267). This 19-year old girl was admitted to the Hospital of the Rockefeller Institute on Sept. 20, 1947 with the complaint of swelling of the legs and abdomen of five-months duration. About two weeks before the onset, she had been vaccinated against small pox and had also contracted poison ivy dermatitis. Physical examination showed generalized edema, ascites and bilateral pleural effusion; the blood pressure was $105 / 75$.

The hospital course is summarized in Figure 16. Daily infusion of $25 \mathrm{Gm}$. and then $50 \mathrm{Gm}$. of albumin per day resulted in steady weight loss; the SCN space decreased about the same amount as the weight. During the sustained diuresis, the loss of chloride could be approximately accounted for on the assumption that only extracellular fluid was lost. On Feb. 10, after recovery, the intake of $\mathrm{NaCl}$ was increased from 21 to $123 \mathrm{mM}$ per day, and the urinary chloride excretion increased until a new equilibrium was reached about on the fifth day (see Figure 5). The 24-hour mean $C_{\text {er }}$ was calculated from aroundthe-clock data, the value of each clearance period being weighted according to its duration. The rate of protein excretion was about $10 \mathrm{Gm}$. per day during the control period. During administration of 25 , then $50 \mathrm{Gm}$. per day of albumin, excretion promptly increased to about 25, then $50 \mathrm{Gm}$. per day. Toward the end of the treatment period protein excretion gradually decreased; within a week after the last albumin infusion, proteinuria disappeared and has not reappeared since. Plasma volume and plasma protein concentrations were measured in the morning before the day's albumin infusion. Albumin was estimated by the Howe method. 

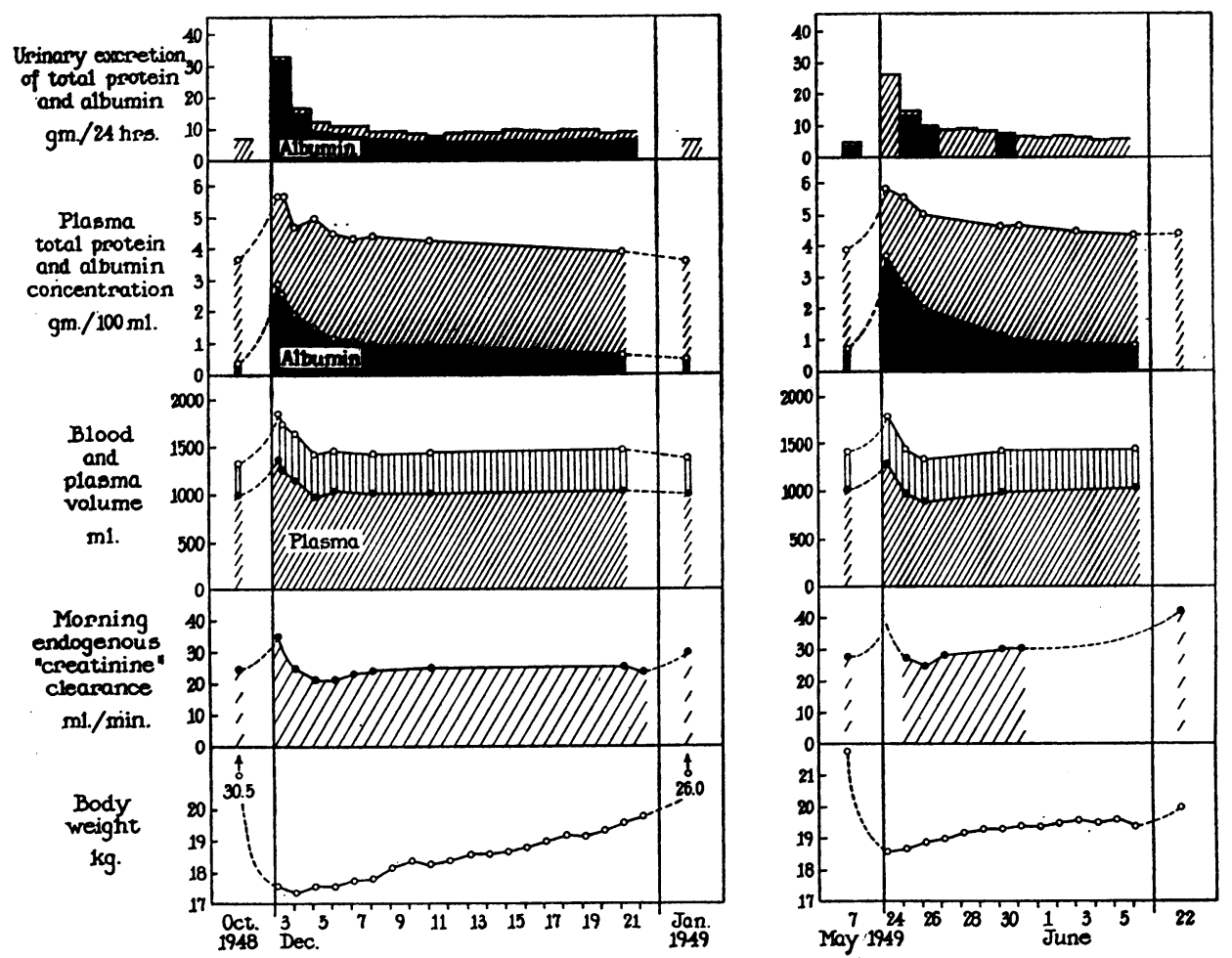

Fig. 13. Sequence of Changes Following Cessation of Administration of 25 Gm. of Albumin per Day in A. McE. Whose Renal Disease Remained Unimproved within Each of the Two Periods Shown

The final dose in both courses was $37.5 \mathrm{Gm}$. In the first two rows, the total height indicates total protein and the solid portion represents albumin determined immunochemically (16). In the fourth row, the values of $C_{c r}$ are averages from several successive periods measured between 6 a.m. and noon.

These data give an indication of the rapidity of changes which might be expected to occur during the first few days following abrupt onset of severe proteinuria. By Dec. 3, 1948 the patient had lost all of her edema as a result of albumin therapy and was outwardly a normal child. On the morning of this day $37.5 \mathrm{Gm}$. were given; within a few hours the plasma albumin concentration had increased to nearly $3 \mathrm{Gm}$. per $100 \mathrm{ml}$., the plasma volume to nearly $1400 \mathrm{ml}$., and $\mathrm{C}_{\mathrm{cr}}$ to the range of 35 to $50 \mathrm{ml}$. per min. These nearly normal values may be regarded as simulating conditions immediately after abrupt onset of severe nephrotic syndrome. During the remainder of this day albumin was excreted at the high average rate of $32 \mathrm{Gm}$. per $24 \mathrm{hrs}$. Within 48 hours the plasma volume and $\mathrm{C}_{\mathrm{cr}}$ had reached minimum values. The rate of weight gain of $0.12 \mathrm{Kg}$. per day was limited by the low salt intake of about $20 \mathrm{mM}$ per day; excretion of sodium was less than $6 \mathrm{mM}$ per day. Had a normal amount of salt been ingested during this time, a much more rapid weight gain would have been expected. The same measurements made after the course of therapy in May, 1949 show the same pattern except that because of a lower albumin clearance (decreased glomerular permeability [16]) the plasma albumin concentration fell more slowly and the rate of formation and the equilibrium volume of edema fluid were less. The final measurements on June 22 were obtained in the out-patient clinic. For additional data before and after these periods, see Figure 14 in the Appendix. 


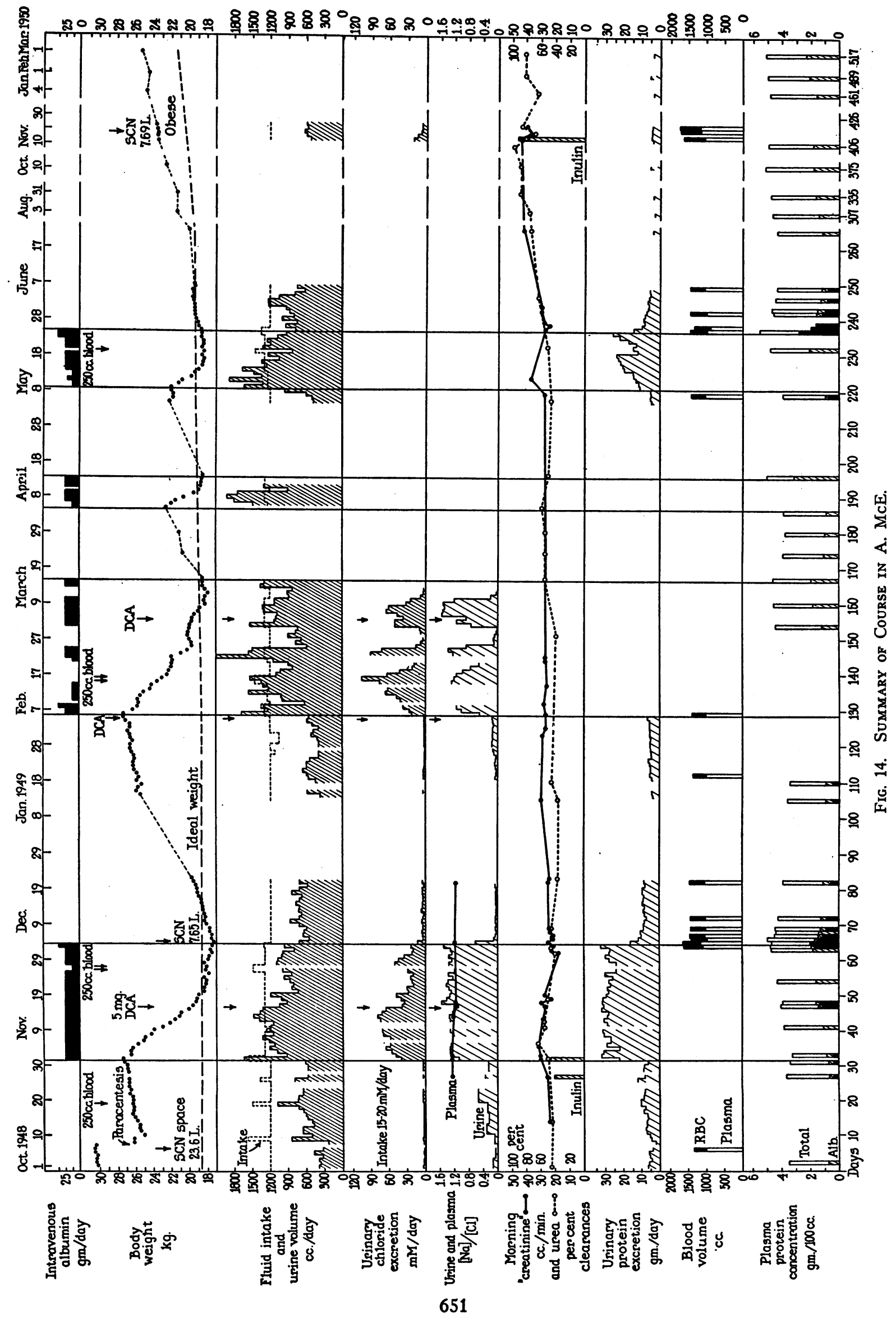




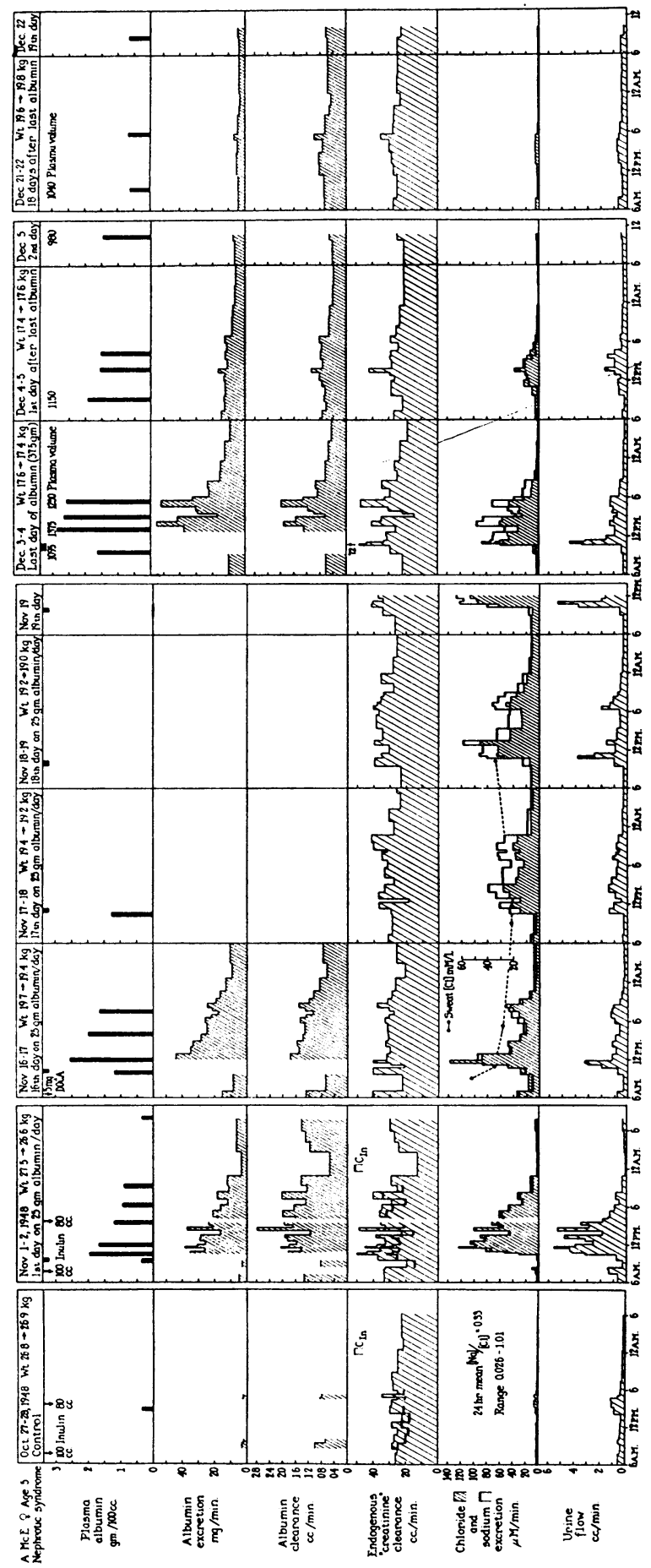

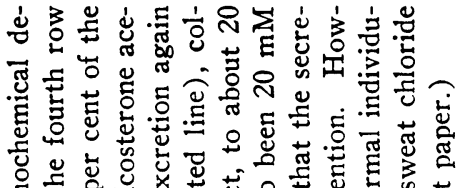

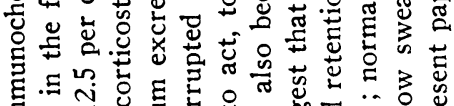

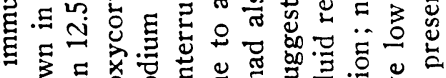

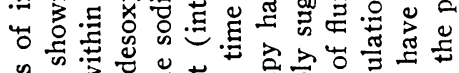

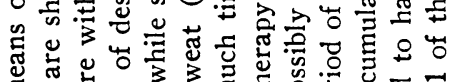

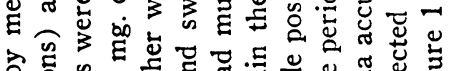

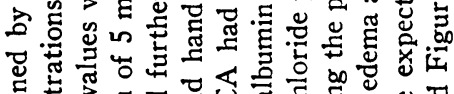

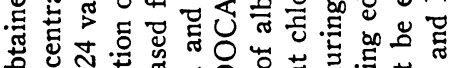

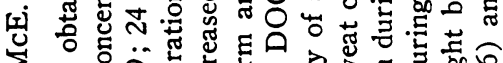
ఫั

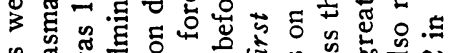

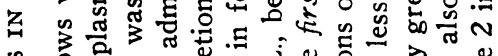

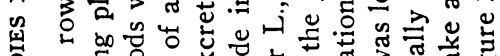

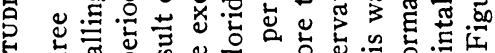

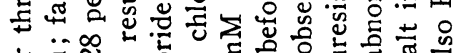

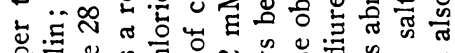

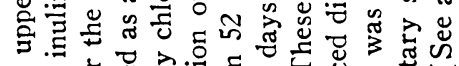

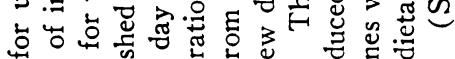

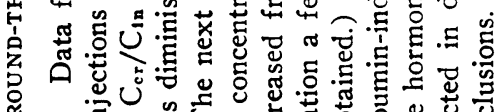

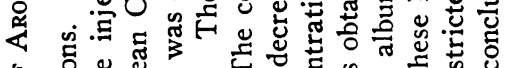

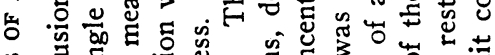

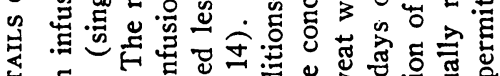

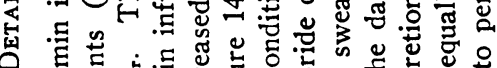

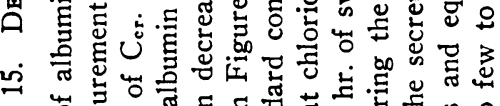
ن

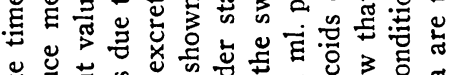

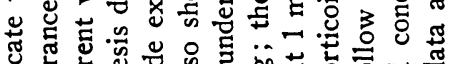

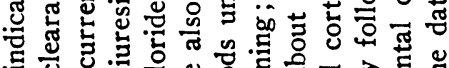

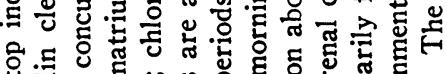

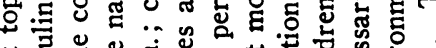

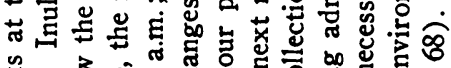

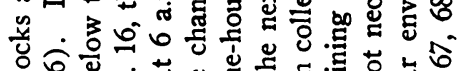

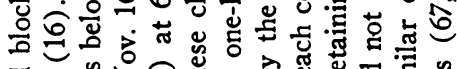

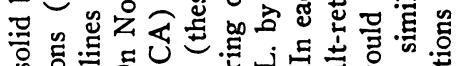

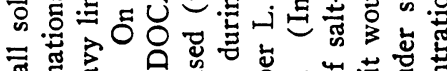

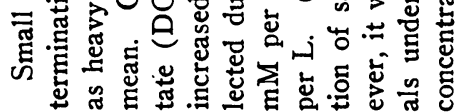




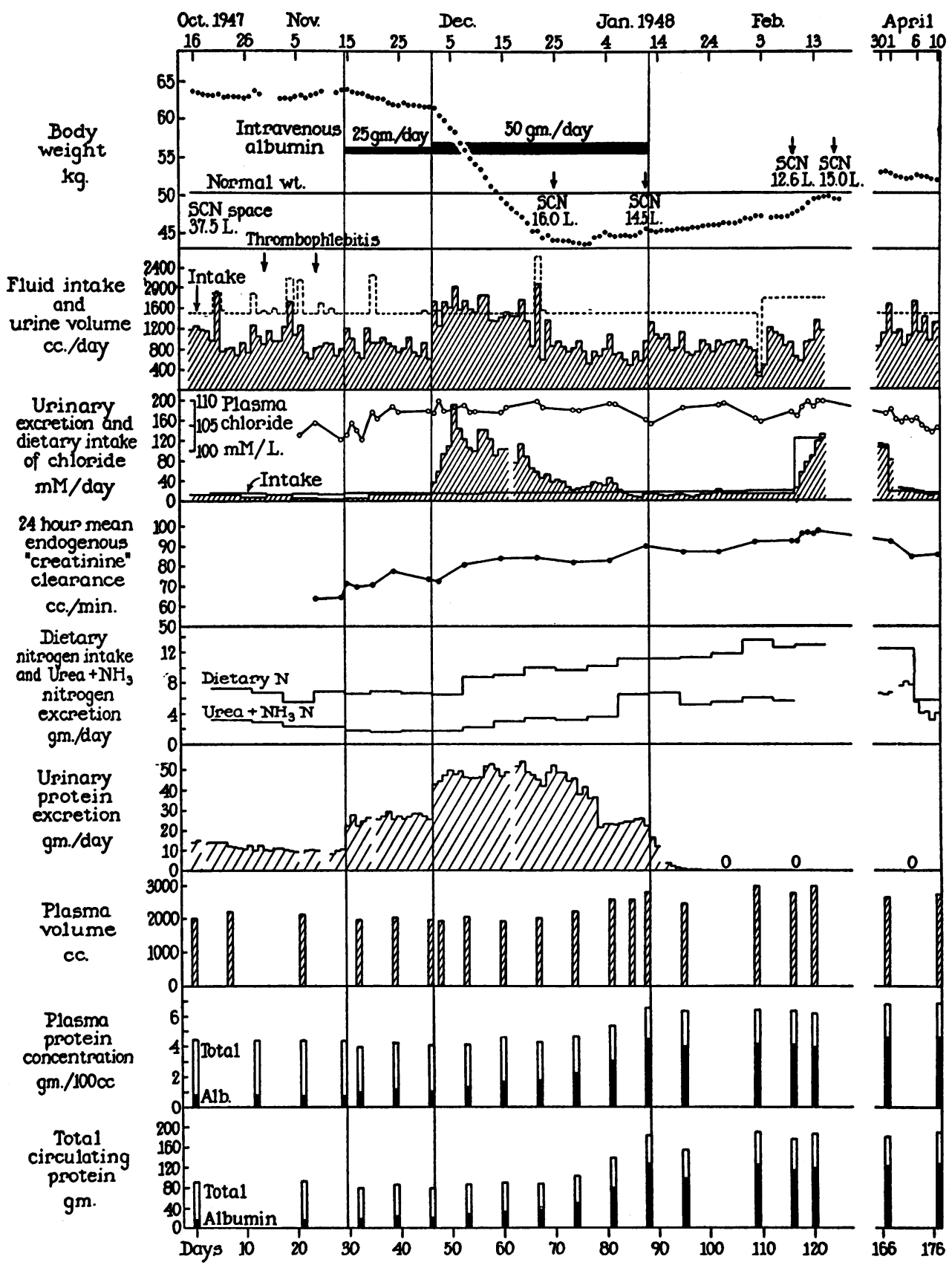

Fig. 16. Summary of Course in C. M. 


\section{REFERENCES}

1. Smith, H. W., The Kidney: Structure and Function in Health and Disease. New York, Oxford University Press, 1951.

2. Barnett, H. L., Forman, C. W., and Lauson, H. D., The nephrotic syndrome in children in Advances in Pediatrics, Levine, S. Z., ed., Chicago, Yearbook Publishers, Inc., vol. V, 1952, p. 53.

3. Earle, D. P., Jr., Taggart, J. V., and Shannon, J. A., Glomerulonephritis. A survey of the functional organization of the kidney in various stages of diffuse glomerulonephritis. J. Clin. Invest., 1944, 23, 119.

4. Bradley, S. E., and Tyson, C. J., The "nephrotic syndrome." New England J. Med., 1948, 238, 223, and 260.

5. Lauson, H. D., Bradley, S. E., and Cournand, A., The renal circulation in shock. J. Clin. Invest., 1944, 23, 381.

6. Phillips, R. A., Dole, V. P., Hamilton, P. B., Emerson, K., Jr., Archibald, R. M., and Van Slyke, D. D., Effects of acute hemorrhagic and traumatic shock on renal function of dogs. Am. J. Physiol., 1946, 145, 314.

7. Thompson, D. D., Barrett, M. J., and Pitts, R. F., Significance of glomerular perfusion in relation to variability of filtration rate. Am. J. Physiol., 1951, 167, 546.

8. Selkurt, E. E., Hall, P. W., and Spencer, M. P., Influence of graded arterial pressure decrement on renal clearance of creatinine, $p$-aminohippurate and sodium. Am. J. Physiol., 1949, 159, 369.

9. Pitts, R. F., and Duggan, J. J., Studies on diuretics. II. The relationship between glomerular filtration rate, proximal tubular absorption of sodium and diuretic efficacy of mercurials. J. Clin. Invest., 1950, 29, 372.

10. Mueller, C. B., Surtshin, A., Carlin, M. R., and White, $H$. L., Glomerular and tubular influences on sodium and water excretion. Am. J. Physiol., 1951, 165, 411.

11. Thompson, D. D., and Pitts, R. F., Effects of alterations of renal arterial pressure on sodium and water excretion. Am. J. Physiol., 1952, 168, 490.

12. Van Slyke, D. D., and Hiller, A., Application of Sendroy's iodometric chloride titration to protein-containing fluids. J. Biol. Chem., 1947, 167, 107.

13. Van Slyke, D. D., Nomogram for correction of low urine chleride values determined by the silver iodate reaction. J. Biol. Chem., 1947, 171, 467.

14. Van Slyke, D. D., and Kugel, V. H., Improvements in manometric micro-kjeldahl and blood urea methods. J. Biol. Chem., 1933, 102, 489.

15. Goldring, W., and Chasis, H., Hypertension and $\mathrm{Hy}-$ pertensive Disease. New York, The Commonwealth Fund, 1944.

16. Chinard, F. P., Lauson, H. D., Eder, H. A., Greif, R. L., and Hiller, A., A study of the mechanism of proteinuria in patients with the nephrotic syndrome. J. Clin. Invest., 1954, 33, 621.

17. Chinard, F. P., Lauson, H. D., Eder, H. A., and Greif, R. L., Plasma volume changes following the administration of albumin to patients with the nephrotic syndrome. J. Clin. Invest., 1954, 33, 629.

18. Shevky, M. C., and Stafford, D. D., A clinical method for the estimation of protein in urine and other body fluids. Arch. Int. Med., 1923, 32, 222.

19. Emerson, K., Jr., Futcher, P. H., and Farr, L. E., The relation of high and low urea clearances to the inulin and creatinine clearances in children with the nephrotic syndrome. J. Clin. Invest., 1941, 20, 361.

20. Emerson, K., Jr., and Dole, V. P., Diodrast and inulin clearances in nephrotic children with supernormal urea clearances. J. Clin. Invest., 1943, 22, 447.

21. Galan, E., Nephrosis in children. I. Observations on eighty-four patients. II. Clearance and saturation tests. Am. J. Dis. Child., 1949, 77, 328.

22. Metcoff, J., Kelsey, W. M., and Janeway, C. A., The nephrotic syndrome in children. An interpretation of its clinical, biochemical, and renal hemodynamic features as variations of a single type of nephron disease. J. Clin. Invest., 1951, 30, 471.

23. Peters, J. P., and Van Slyke, D. D., Quantitative Clinical Chemistry. Vol. II. Methods. Williams \& Wilkins, Baltimore, 1932.

24. Corcoran, A. C., and Page, I. H., A method for the determination of mannitol in plasma and urine. J. Biol. Chem., 1947, 170, 165.

25. Taggart, J. V., Protein binding of $p$-aminohippurate in human and dog plasma. Am. J. Physiol., 1951, $167,248$.

26. Miller, B. F., and Van Slyke, D. D., A direct microtitration method for blood sugar. J. Biol. Chem., 1936, 114, 583.

27. Marshall, E. K., Jr., and Kolls, A. C., Studies on the nervous control of the kidney in relation to diuresis and urinary secretion. II. A comparison of the changes caused by unilateral splanchnotomy with those caused by unilateral compression of the renal artery. Am. J. Physiol., 1919, 49, 317.

28. Shannon, J. A., The control of the renal excretion of water. I. The effect of variations in the state of hydration on water excretion in dogs with diabetes insipidus. J. Exper. Med., 1942, 76, 371.

29. Hall, P. W., III, and Selkurt, E. E., Effects of partial graded venous obstruction on electrolyte clearance by the dog's kidney. Am. J. Physiol., 1951, 164, 143.

30. Selkurt, E. E., Physical factors in relation to electrolyte and water excretion in Bradley, S. E., ed., Renal Function, Trans. of the Third Conference, Oct. 18-19, 1951, Josiah Macy, Jr. Foundation, New York, 1952, p. 103.

31. Post, R. S., Decrease of cardiac output by acute pericardial effusion and its effect on renal hemo- 
dynamics and electrolyte excretion. Am. J. Physiol., 1951, 165, 278.

32. Lauson, H. D., and Thompson, D. D., Unpublished observations.

33. Brun, C., Knudsen, E. O. E., and Raaschou, F., On the cause of post-syncopal oliguria. Acta med. Scandinav., 1945, 122, 486.

34. Merrill, A. J., Mechanisms of salt and water retention in heart failure. Am. J. Med., 1949, 6, 357.

35. Barnett, H. L., Forman, C. W., McNamara, H., McCrory, W. W., Rapoport, M., Michie, A. J., and Barbero, G., The effect of adrenocorticotrophic hormone on children with the nephrotic syndrome. II. Physiologic observations on discrete kidney functions and plasma volume. J. Clin. Invest., 1951, 30, 227.

36. Luetscher, J. A., Jr., and Deming, Q. B., Treatment of nephrosis with cortisone. J. Clin. Invest., 1950, 29, 1576.

37. Luetscher, J. A., Jr., Deming, Q. B., and Johnson, B. B., Treatment of nephrosis with pituitary adrenocorticotrophin. J. Clin. Invest., 1951, 30, 1530.

38. Metcoff, J., Rance, C. P., Kelsey, W. M., Nakasone, N., and Janeway, C. A., Adrenocorticotrophic hormone (ACTH) therapy of the nephrotic syndrome in children. Pediatrics, 1952, 10, 543.

39. Burnett, C. H., Burrows, B. A., and Commons, R. R., The lack of correlation between glomerular filtration rate, and serum electrolyte concentration changes, urinary electrolyte excretion, or edema formation following sodium loads in subjects with normal kidneys, glomerulonephritis, and the nephrotic syndrome. J. Clin. Invest., 1949, 28, 773.

40. Metcoff, J., and Wallace, W. M., The nephrotic syndrome in children: Response to intravenous sodium loads. J. Clin. Invest., 1950, 29, 835.

41. Metcoff, J., Rance, C. P., and Nakasone, N., Observations on renal mechanisms for sodium and potassium excretion in ACTH-induced diuresis of nephrotic edema. J. Clin. Invest., 1951, 30, 661.

42. Ingbar, S. H., Kass, E. H., Burnett, C. H., Relman, A. S., Burrows, B. A., and Sisson, J. H., The effects of ACTH and cortisone on the renal tubular transport of uric acid, phosphorus, and electrolytes in patients with normal renal and adrenal function. J. Lab. \& Clin. Med., 1951, 38, 533.

43. Lauson, H. D., and Thompson, D. D., Effects of decrease in glomerular filtration rate on cation excretion during loading with nonreabsorbable anions. Federation Proc., 1953, 12, 83.

44. Chinard, F. P., and Eder, H. A., The determination of the concentration of the dye T-1824 in normal and lipemic plasmas. J. Exper. Med., 1948, 87, 473.

45. Morse, M., Cassels, D. E., and Schlutz, F. W., Blood volumes of normal children. Am. J. Physiol., 1947, $151,448$.

46. Russell, S. J. M., Blood volume studies in healthy children. Arch. Dis. Childhood, 1949, 24, 88.

47. Fremont-Smith, F., The mechanism of edema formation. New England J. Med., 1932, 206, 1286.
48. Robinson, F. H., Jr., and Farr, L. E., The relation between clinical edema and the excretion of an antidiuretic substance in the urine. Ann. Int. Med., 1940, 14, 42.

49. de Oliveira, H. L., and de Assis, L. M., Regressão da síndrome nefrótica emum caso tratado pelo ACTH. Estudo da excreção urinária de cloro, sódio e princípios anti-diuréticos. Rev. Hosp clín., 1950, 5, 139.

50. Shorr, E., Baez, S., Zweifach, B. W., Payne, M. A., and Mazur, A., The antidiuretic action of the hepatic vasodepressor ferritin (VDM) and its occurrence in conditions associated with antidiuresis in man. Tr. A. Am. Physicians, 1950, 63, 39.

51. Baez, S., Mazur, A., and Shorr, E., Role of the neurohypophysis in ferritin-induced antidiuresis. Am. J. Physiol., 1952, 169, 123.

52. Deming, Q. B., and Luetscher, J. A., Jr., Bioassay of desoxycorticosterone-like material in urine. Proc. Soc. Exper. Biol. \& Med., 1950, 73, 171.

53. Luetscher, J. A., Jr., and Deming, Q. B., Bioassay of sodium-retaining corticoids and some changes in excretion of these substances in disease in Bradley, S. E., ed., Renal Function, Trans. of the Second Conference, Oct. 19-20, 1950, Josiah Macy, Jr. Foundation, New York, 1951, p. 155.

54. Conn, J. W., Electrolyte composition of sweat. Clinical implications as an index of adrenal cortical function. Arch. Int. Med., 1949, 83, 416.

55. Warming-Larson, A., and Wallace, W. M., Studies of the volume and composition of sweat during diuresis in patients with nephrosis. J. Clin. Invest., 1951, $30,680$.

56. Baxter, J. H., and Cotzias, G. C., Effects of proteinuria on the kidney. Proteinuria, renal enlargement, and renal injury consequent on protracted parenteral administration of protein solutions in rats. J. Exper. Med., 1949, 89, 643.

57. Bradley, S. E., Bradley, G. P., Tyson, C. J., Curry, J. J., and Blake, W. D., Renal function in renal diseases. Am. J. Med., 1950, 9, 766.

58. Blake, W. D., Wégria, R., Keating, R. P., and Ward, $H$. P., Effect of increased renal venous pressure on renal function. Am. J. Physiol., 1949, 157, 1.

59. Marshall, E. K., Jr., and Kolls, A. C., Studies on the nervous control of the kidney in relation to diuresis and urinary secretion. I. The effect of unilateral excision of the adrenal, section of the splanchnic nerve and section of the renal nerves on the secretion of the kidney. Am. J. Physiol., 1919, 49, 302.

60. Kriss, J. P., Futcher, P. H., and Goldman, M. L., Unilateral adrenalectomy, unilateral splanchnic nerve resection and homolateral renal function. Am. J. Physiol., 1948, 154, 229.

61. Kaplan, S. A., and Rapoport, S., Urinary excretion of sodium and chloride after splanchnicotomy; effect on the proximal tubule. Am. J. Physiol., 1951, 164, 175. 
62. Kaplan, S. A., Fomon, S. J., and Rapoport, S., Effect of splanchnic nerve division on urinary excretion of electrolytes during mannitol loading in the hydropenic dog. Am. J. Physiol., 1951, 166, 641.

63. Surtshin, A., Mueller, C. B., and White, H. L., Effect of acute changes in glomerular filtration rate on water and electrolyte excretion: mechanism of denervation diuresis. Am. J. Physiol., 1952, 169, 159.

64. Berne, R. M., Hemodynamics and sodium excretion of denervated kidney in anesthetized and unanesthetized dog. Am. J. Physiol., 1952, 171, 148.

65. Chinard, F. P., Lauson, H. D., and Eder, H. A., Relationship of the renal clearances of T-1824 and of albumin in some patients with proteinuria. J. Clin. Invest., 1952, 31, 895.

66. Eder, H. A., Determination of thiocyanate space in Visscher, M. B., ed., Methods in Medical Research, Chicago, The Year Book Publishers, Inc., 1951, vol. 4 , p. 48.

67. Conn, J. W., The mechanism of acclimatization to heat in Dock, W., and Snapper, I., eds., Advances in Internal Medicine, New York, Interscience Publishers, Inc., 1949, vol. III, p. 373.

68. Locke, W., Talbot, N. B., Jones, H. S., and Worcester, J., Studies on the combined use of measurements of sweat electrolyte composition and rate of sweating as an index of adrenal cortical activity. J. Clin. Invest., 1951, 30, 325. 